\title{
THE EMBRYONIC HISTORY OF THE GERM CELLS OF THE LARGEMOUTH BLACK BASS, MICROPTERUS SALMOIDES SALMOIDES (LACÉPEDE) ${ }^{1}$
}

PERRY MAX JOHNSTON ${ }^{2}$

Department of Zoology, University of Michigan, Ann Arbor

FIFTY-TWO FIGURES

\section{INTRODUCTION}

An extensive literature has accumulated dealing with the early history of the germ cells in animals and, although the initial studies were concerned with invertebrate groups, some of the more complete ones have dealt with vertebrates. Interest in this problem was stimulated when it seemed imperative that the germ cells must remain unchanged from generation to generation in order to pass on the hereditary characteristics of the species. Theoretically, therefore, the germ cells must be set aside at some early stage of development and withheld from the assumption of any somatic duties.

Although it is possible to trace the germ cells back to early stages of development in certain of the invertebrates ( $A s$ caris, Miastor, Sagitta and others), such is not the case for the vertebrates. The only example of such an early segregation for these forms is that of Micrometrus aggregatus reported by Eigenmann in 1891. In this form, it was claimed by Eigenmann that the germ cells could be recognized as distinct from the soma as early as the 5th or 6th segmentation. Although others have tried, none has succeeded in the years

${ }^{1}$ Part II of a dissertation submitted in partial fulfilment of the requirement for the degree of Doctor of Philosophy in the University of Michigan.

2 Present address, Department of Zoology, University of Arkansas, Fayetterille, Arkansas. 
since to trace the germ cells so far back in the ontogeny of a vertebrate species.

Whereas numerous accounts dealing with the germ cell history in fishes have appeared in literature, none that approaches completeness has dealt with a representative of the sunfish family, the Centrarchidae. Recognizing the need of a careful morphological study of the germ cells in a member of this group, this investigation was undertaken. The embryonic stages of the largemouth black bass, Micropterus salmoides salmoides (Lacépède) were used to determine the stage of development during which the primordial germ cells could first be recognized and then to record their subsequent history up to the period of sex differentiation.

I wish to express my sincere appreciation to Dr. Peter Okkelberg, under whose direction the investigation was carried out, for his most valuable help and criticism; and also to Dr. A. E. Woodward, Dr. Alfred H. Stockard, Dr. Karl F. Lagler of the Department of Zoology, and Dr. Bradley M. Patten of the Department of Anatomy of the School of Medicine of the University of Michigan, all of whom read and criticized the manuscript ; and to Mr. E. R. Widmyer, Superintendent, U. S. Fish and Wildlife Service Hatchery, Northville, Michigan, for his assistance in securing the necessary material used in this investigation.

\section{MATERIALS AND METHODS}

Most of the material used in this investigation came from the U. S. Fish and Wildlife Service Hatchery at Northville, Michigan. Additional collections of unaged fry and fingerling were made from the Huron River and from Whitmore Lake, both in Washtenaw County, Michigan.

Four series of developmental stages were collected for study: the first in the spring of 1946, the second and third in the spring of 1947 and the 4th in the spring of 1948. Freshly spawned eggs were siphoned from the nests by means 
of a glass tube. A pair of long-handled lawn trimmers was employed to snip off rootlets with adhering eggs. The first series was collected and fixed at the nesting sites while the second, third, and 4th series were reared and hatched in the laboratory. The first series was composed of stages ranging from the freshly laid egg to young of two to three inches in length, the second and third series were made up of embryos fixed every two hours until hatching, and the 4th series consisted of embryos fixed at two hour intervals up to the 18th hour and then every 4 hours until hatching.

Several fixatives were employed, including Benda's fluid, Bouin's, Allen's Modification of Bouin's with chromic acid, Meves' solution, $10 \%$ formalin and various strengths of alcohol. While none of these gave perfect results as yolk fixatives, the best cellular fixation was obtained with Bouin's to which had been added one gram of urea crystals per 105 parts.

Three methods of dehydration and clearing were used; the conventional xylol and alcohol method, N-Butyl alcohol, and Dioxane. The best results were obtained with Dioxane. Because Dioxane is miscible in all proportions with water, alcohol, and xylol and is a paraffin solvent, dehydration and clearing can be combined in one operation. It was found that whole embryos could be transferred directly from the fixative into Dioxane. After a period of time, varying in length with the size of the embryos, direct transfer could be made into paraffin. While in paraffin, care was taken to prevent them from resting on the bottom of the container. Bituminous assay crucibles made of glazed porcelain were used for this purpose. This was necessary because Dioxane, although a paraffin solvent, has a greater specific gravity than melted paraffin and sinks to the bottom of the dish. Thus, if the embryos are not supported above the bottom, little or no infiltration of paraffin can take place. Best results were obtained when two or three changes of paraffin were made. One of the many advantages of the Dioxane method is that tissues may be left for hours or even days in the Dioxane-paraffin mixtures without becoming excessively brittle. 
After infiltration, the embryos were embedded in Fisher Tissuemat, $56-58^{\circ} \mathrm{C}$, and sectioned at 8 and $10 \mu$, the majority being cut at $10 \mu$.

Complete serial sections of all prehatching stages were mounted and stained. This procedure was extended to include posthatching stages up to $13-\mathrm{mm}$ in length. Subsequently, only the trunk portion was used. In larger specimens, fingerlings and older, only the swimbladder and the attached gonads were prepared for study.

The four stains used were: Harris' Hematoxylin, Heidenhain's Iron Hematoxylin, Mallory's triple and Heidenhain's Azan. Harris' Hematoxylin and Heidenhain's Iron Hematoxylin were used most frequently and although it has been claimed that Dioxane impairs the staining quality of the nucleus when stained with Harris' Hematoxylin, I encountered no such difficulty.

To designate the developmental stage for prehatching embryos the age in hours was employed, and for posthatching, larvae, fry and fingerlings the total length in millimeters or centimeters.

\section{HISTORICAL RÉSUMÉ}

Considerable literature exists concerning the history of the germ cells in vertebrates. Three theories have been proposed to account for their origin. These are the "Germinal Epithelium Theory" of Waldeyer (1870), the "Early Segregation Theory" of Nussbaum (1880) and the "Gonotome Theory" of Ruckert (1888). In spite of the various researches supporting or refuting these theories, controversy and disagreement still exist regarding the origin, mode of migration, marks of identification, and ultimate fate of the germ cells. Heys ('31) and Everett ('45) have summarized the various existing ideas and have grouped them into 4 schools of thought: (1) those who do not accept the idea of an early segregation of the germ cells (Hargitt, Simkins, Von Berenberg-Gossler and others); (2) those who admit an early segregation of the germ cells but believe that these degenerate and do not give rise to the definitive reproductive cells 
(Felix, B. Allen, Firket, Kingery and others) ; (3) those who believe that the germ cells arise both from the soma and from primordial germ cells (Humphrey, Brambell, B. Allen, Beccari, Burns, McCosh and others); and (4) those who believe that the early segragrated cells are the only source of definitive sex cells (Nussbaum, Okkelberg, Beard, Eigenmann, Witschi, Burns, Cheng, Blocker, Everett and others).

Although very few of the investigations considered by Heys ('31) and Everett ('45) dealt with the germ cell history of fishes, it is not surprising to find that the same differences of opinion exist among those who have studied the problem in this group (table 1).

Table 1 is a summary of some of the literature concerning the history of germ cells in vertebrates which has appeared since 1870. Some of that pertaining to fishes will be treated more fully in the Discussion.

\section{OBSERVATIONS ON MICROPTERUS SALMOIDES SALMOIDES}

\section{Characteristics of the germ cells}

Although descriptions of germ cells of vertebrates differ in detail, certain general characteristics have been ascribed to them. The early germ cells usually are characterized by yolk granules and attraction spheres in their cytoplasm, by their large size and definite nuclear and cellular membranes, by their darkly staining nuclei and hyaline cytoplasm, and by their ability to migrate independently. Less commonly observed features are the extrusion of plasmosomal bodies into the cytoplasm (Dodds, '10), difference in the shape of their mitochondria as compared to somatic cells (Rubaschkin, '10; Tschaschkin, '10), possession of vitelline bodies (King, '08; Okkelberg, '21), peculiar configuration of their Golgi bodies (Woodger, '25), and the characteristic peripheral arrangement of the chromatin in the nucleus (Richards and Thompson, '21). Most investigators prefer to rely not only on any particular characteristic for their identification but on the general appearance of the germ cell itself, because it has been 
TABLE 1

Summary of some of the literature dealing with the origin of germ cells in vertebrates

\begin{tabular}{|c|c|c|c|}
\hline AUTHOR & DATE & ANIMAL $x$ & REMARKS ON GERM OELLS \\
\hline \multicolumn{4}{|c|}{ Cyclostomes } \\
\hline Goette & 1890 & $\begin{array}{l}\text { Petromyzon } \\
\text { fluviatilis }\end{array}$ & Germ cells come from mesoderm. \\
\hline Wheeler & 1899 & $\begin{array}{l}\text { Petromyzon } \\
\text { planeri }\end{array}$ & Germ cells from blastoderm. \\
\hline Beard & $1902 \mathrm{~b}$ & Petromyzon & Germ cells are early segregated cells. \\
\hline Okkelberg & 1921 & $\begin{array}{l}\text { Entosphenus } \\
\text { wilderi }\end{array}$ & $\begin{array}{l}\text { Definitive germ cells from early segregated } \\
\text { cells. }\end{array}$ \\
\hline Buteher & 1929 & $\begin{array}{l}\text { Petromyzon } \\
\text { marinus unicolor }\end{array}$ & $\begin{array}{l}\text { Dual origin of germ cells: (a) from early segre- } \\
\text { gated cells; (b) from coelomic epithelium. }\end{array}$ \\
\hline \multicolumn{4}{|c|}{ Elasmobranchs } \\
\hline Semper & 1875 & Plagiostomes & Germ cells from coelomic epithelium. \\
\hline Balfour & 1877 & $\begin{array}{l}\text { Seyllium } \\
\text { Pristiurus }\end{array}$ & Germ cells probably from mesoderm. \\
\hline Ruckert & 1888 & Pristiurus & Germ cells from gonotome. \\
\hline Van Wijhe & 1889 & $\begin{array}{l}\text { Seyllium } \\
\text { Pristiurus }\end{array}$ & Germ cells from gonotome. \\
\hline Rabl & 1896 & Pristiurus & Germ cells found extra-regionally. \\
\hline Beard & $\begin{array}{l}1900 \\
1902 a\end{array}$ & $\begin{array}{l}\text { Raja batis } \\
\text { Pristiurus }\end{array}$ & Germ cells from early segregaterl cells. \\
\hline Woods & 1902 & $\begin{array}{l}\text { Squalus } \\
\text { acanthias }\end{array}$ & Germ cells first seen in entoderm. \\
\hline \multicolumn{4}{|c|}{$\begin{array}{l}\text { Actinopterygians } \\
\quad(\text { Berg, '40) }\end{array}$} \\
\hline Allen & $1911 a$ & $\begin{array}{l}\text { Amia } \\
\text { Lepidosteus }\end{array}$ & Germ cells from early segregated cells. \\
\hline Nussbaum & 1880 & Trout & $\begin{array}{l}\text { Germ cells from early segregated cells, not de- } \\
\text { rived from mesoderm. }\end{array}$ \\
\hline MacLeod & 1881 & $\begin{array}{l}\text { Hippocampus } \\
\text { Belone }\end{array}$ & Germ cells from germinal epithelium. \\
\hline Hoffmann & 1886 & Salmon & Germ cells from peritoneum. \\
\hline Eigenmann & 1891 & $\begin{array}{r}\text { Micrometrus } \\
\text { aggregatus }\end{array}$ & $\begin{array}{l}\text { Germ cells early segmentation cells of } 5 \text { th and } \\
6 \text { th cleavage of the egg. }\end{array}$ \\
\hline Bohi & 1904 & $\begin{array}{l}\text { Trout } \\
\text { Salmon }\end{array}$ & Germ cells from germinal epithelium. \\
\hline Fedorow & 1907 & Salmo fario & $\begin{array}{l}\text { Germ cells in somatopleure and splanehno- } \\
\text { pleure. }\end{array}$ \\
\hline
\end{tabular}


TABLE 1 (continued)

\begin{tabular}{|c|c|c|c|}
\hline AUTHOR & DATE & ANIMAL ${ }^{1}$ & REMARKS ON GERM CELLS \\
\hline \multicolumn{4}{|c|}{$\begin{array}{c}\text { Actinopterygians (continued) } \\
\text { (Berg, '40) }\end{array}$} \\
\hline Dodds & 1910 & $\begin{array}{l}\text { Lophius } \\
\text { piscatorius }\end{array}$ & Germ cells are early segregated cells. \\
\hline Bachmann & 1914 & $\begin{array}{l}\text { Amiurus } \\
\text { nebulosus }\end{array}$ & Germ cells from early segregated cells. \\
\hline $\begin{array}{l}\text { Riehards and } \\
\text { Thompson }\end{array}$ & 1921 & $\begin{array}{l}\text { Fundulus } \\
\text { heteroclitus }\end{array}$ & Germ eells are early segregated cells. \\
\hline Essenberg & 1923 & $\begin{array}{l}\text { Xiphophorus } \\
\text { helleri }\end{array}$ & $\begin{array}{l}\text { Female: germ cells from ovarian cortex and } \\
\text { epithelium of ovary. Male: from the epithe- } \\
\text { lium of tubules. }\end{array}$ \\
\hline Reinhard & 1924 & Scardinius & Germ cells from giant cells of periblast. \\
\hline Van Oordt & 1924 & $\begin{array}{l}\text { Xiphophorus } \\
\text { helleri }\end{array}$ & Male: germ cells from epithelium of tubules. \\
\hline Hann & 1927 & $\begin{array}{l}\text { Cottus } \\
\text { bairdii }\end{array}$ & Germ cells from giant entodermal cells. \\
\hline Foley & 1927 & $\begin{array}{l}\text { Umbra } \\
\text { limi (male) }\end{array}$ & Spermatogonia from stromal cells of testis. \\
\hline Wolf & 1931 & $\begin{array}{l}\text { Platypoecilus } \\
\text { maculatus }\end{array}$ & $\begin{array}{l}\text { Male: spermatogonia from primordial cells. Fe- } \\
\text { male: ova from primordial cells and germinal } \\
\text { epithelium. }\end{array}$ \\
\hline $\begin{array}{l}\text { Goodrich } \\
\text { et al. }\end{array}$ & 1934 & $\begin{array}{l}\text { Lebistes } \\
\text { reticulatus }\end{array}$ & $\begin{array}{l}\text { Germ cells are early segregated cells first seen in } \\
\text { mesentoderm. }\end{array}$ \\
\hline $\begin{array}{l}\text { Maschkow- } \\
\text { ziff }\end{array}$ & 1934 & $\begin{array}{l}\text { Acipenser } \\
\text { stellatus } \\
\text { Salmo trutta }\end{array}$ & $\begin{array}{l}\text { Primordial germ cells found in gut entoderm. } \\
\text { Dimorphic from very beginning. }\end{array}$ \\
\hline Bennington & 1936 & $\begin{array}{l}\text { Betta } \\
\text { splendens }\end{array}$ & $\begin{array}{l}\text { Adult males: germ cells from residual cells- } \\
\text { descendants of primordial germ cells. }\end{array}$ \\
\hline Dildine & 1936 & $\begin{array}{l}\text { Lebistes } \\
\text { reticulatus }\end{array}$ & $\begin{array}{l}\text { Germ cells seen in mesentoderm soon after gas- } \\
\text { trulation. }\end{array}$ \\
\hline Odum & 1936 & Opsanus tau & $\begin{array}{l}\text { Germ cells occur in two strands in post coelomie } \\
\text { region. }\end{array}$ \\
\hline Moore & 1937 & Salmo irideus & Germ cells are early segregation cells. \\
\hline \multicolumn{4}{|c|}{ Amphibians } \\
\hline Nussbaum & 1880 & Rana fusca & Germ cells are early segregated cells. \\
\hline Hoffmann & 1886 & $\begin{array}{l}\text { Triton, Rana } \\
\text { Bufo }\end{array}$ & Germ celis from germinal epithelium. \\
\hline Semon & 1891 & $\begin{array}{l}\text { Iehthyophis } \\
\text { glutinosus }\end{array}$ & Germ cells from the germinal epithelium. \\
\hline
\end{tabular}


TABLE 1 (continued)

\begin{tabular}{|c|c|c|c|}
\hline AUTHOR & DATE & ANIMAL $i$ & REMARKS ON GKRM CELILS \\
\hline \multicolumn{4}{|c|}{ Amphibians (continued) } \\
\hline Bouin & $\begin{array}{l}1900 \\
1901\end{array}$ & $\begin{array}{l}\text { Rana } \\
\text { temporaria }\end{array}$ & $\begin{array}{l}\text { Germ cells from early segregated cells and from } \\
\text { peritoneal and mesenchymal cells. }\end{array}$ \\
\hline Hall & 1904 & $\begin{array}{r}\text { Ambystoma } \\
\text { punctatum }\end{array}$ & Germ cells from a gonotome. \\
\hline Allen & $1907 \mathrm{~b}$ & Rana pipiens & $\begin{array}{l}\text { Germ cells from early segregated cells, first seen } \\
\text { in entoderm. }\end{array}$ \\
\hline Dustin & 1907 & $\begin{array}{l}\text { Triton } \\
\text { alpestris } \\
\text { Rana fusea } \\
\text { Bufo vulgaris }\end{array}$ & $\begin{array}{l}\text { Germ cells from the gonotome and from peri- } \\
\text { toneal cells. }\end{array}$ \\
\hline King & 1908 & $\begin{array}{l}\text { Bufo } \\
\text { lentiginosus }\end{array}$ & $\begin{array}{l}\text { Germ. cells originate in entoderm, migrate into } \\
\text { the mesoderm. }\end{array}$ \\
\hline $\begin{array}{l}\text { Kuschake- } \\
\text { witseh }\end{array}$ & 1910 & Rana esculenta & $\begin{array}{l}\text { Primary germ cells from early segregated cells, } \\
\text { functional germ cells from mesenchyme and } \\
\text { peritoneum. }\end{array}$ \\
\hline Allen & $1911 b$ & $\begin{array}{l}\text { Ambystoma } \\
\text { Necturus }\end{array}$ & $\begin{array}{l}\text { Germ cells from mesoderm lying between myo- } \\
\text { tome and lateral plate. }\end{array}$ \\
\hline Schapitz & 1912 & $\begin{array}{c}\text { Ambystoma } \\
\text { mexicanum }\end{array}$ & Germ cells from the gonotome. \\
\hline $\begin{array}{l}\text { SpehI and } \\
\text { Polus }\end{array}$ & 1912 & $\begin{array}{l}\text { Ambystoma } \\
\text { tigrinum }\end{array}$ & Germ cells from gonotome and peritoneal cells. \\
\hline Abramowicz & 1913 & Triton taeniatus & $\begin{array}{l}\text { Primary germ cells from entoderm; secondary } \\
\text { from mesoderm. }\end{array}$ \\
\hline Champy & 1913 & $\begin{array}{l}\text { Triton palmatus } \\
\text { Rana temporaria }\end{array}$ & Germ cells from gonotome. \\
\hline Witsehi & 1914 & Rana temporaria & Germ cells first found in entoderm. \\
\hline Gatenby & 1916 & Rana temporaria & $\begin{array}{l}\text { Germ cells of adults originate seasonally from } \\
\text { peritoneal cells. }\end{array}$ \\
\hline Swingle & $\begin{array}{l}1921 \\
1926\end{array}$ & Rana catesbeiana & $\begin{array}{l}\text { Primordial germ eells from entoderm. Second- } \\
\text { ary cells from descendants of primary cells. }\end{array}$ \\
\hline \multirow[t]{2}{*}{ Beceari } & 1922 & $\begin{array}{l}\text { Salamandrina } \\
\text { perspicillata }\end{array}$ & Germ cells from mesoderm (gonotome). \\
\hline & 1924 & Bufo viridis & $\begin{array}{l}\text { Germ cells first seen in the entoderm, later mi- } \\
\text { grate to genital ridge. }\end{array}$ \\
\hline Hargitt & 1924 & $\begin{array}{c}\text { Diemyctylus } \\
\text { viridescens }\end{array}$ & $\begin{array}{l}\text { Germ cells derived from epithelium of collecting } \\
\text { ducts and germinal epithelium. }\end{array}$ \\
\hline Bounoure & $\begin{array}{l}1924 b \\
1925 \\
1924 a\end{array}$ & $\begin{array}{l}\text { Triton alpestris } \\
\text { Rana temporaria } \\
\text { Bufo vulgaris }\end{array}$ & Germ cells first found in entoderm. \\
\hline
\end{tabular}


TABLE 1 (continued)

\begin{tabular}{|c|c|c|c|}
\hline AUTHOR & DATE & ANIMAL $x$ & REMARKS ON GERM CEILS \\
\hline \multicolumn{4}{|c|}{ Amphibians (continued) } \\
\hline Obreshkove & 1924 & $\begin{array}{l}\text { Diemyctylus } \\
\text { viridescens }\end{array}$ & $\begin{array}{l}\text { Strong possibility of stromal transition into } \\
\text { germ cells. }\end{array}$ \\
\hline Humphrey & 1925 & $\begin{array}{l}\text { Rana pipiens } \\
\text { (and others) } \\
\text { Triturus } \\
\text { viridescens } \\
\text { (and others) }\end{array}$ & $\begin{array}{l}\text { Germ cells appear first in entoderm. Germ cells } \\
\text { appear first in medial part of lateral plate } \\
\text { mesoderm. }\end{array}$ \\
\hline Burns & 1925 & $\begin{array}{r}\text { Ambystoma } \\
\text { punctatum }\end{array}$ & Germ cells are early segregated cells. \\
\hline Perle & 1927 & Bufo vulgaris & Germ cells located first in entoderm. \\
\hline Witschi & 1929 & Rana sylvatica & Germ cells originate in entoderm. \\
\hline Christensen & 1930 & Rana pipiens & Germ cells seen in entoderm. \\
\hline Chen & 1930 & $\begin{array}{l}\text { Necturus } \\
\text { maculosus }\end{array}$ & Germ cells from mesoderm. \\
\hline MeCosh & 1930 & $\begin{array}{r}\text { Ambystoma } \\
\text { maculatum }\end{array}$ & $\begin{array}{l}\text { Germ cells from lateral mesoderm - somatic in } \\
\text { origin. }\end{array}$ \\
\hline Cheng & $\begin{array}{l}1932 a \\
1932 b\end{array}$ & $\begin{array}{l}\text { Rana catabri- } \\
\text { gensis }\end{array}$ & Germ cells are early segregation cells. \\
\hline Bounoure & 1934 & Rana temporaria & $\begin{array}{l}\text { Germ cells determined by presence of a "cyto- } \\
\text { plasm germinale", first located at posterior } \\
\text { pole of egg. }\end{array}$ \\
\hline Fischer & 1935 & Axolot1 & Germ cells from primary gonoeytes (germ cells). \\
\hline Burger & 1937 & $\begin{array}{l}\text { Plethodon } \\
\text { cinereus }\end{array}$ & $\begin{array}{l}\text { Primordial germ cells give rise to definitive sex } \\
\text { cells. }\end{array}$ \\
\hline Seshachar & 1937 & $\begin{array}{l}\text { Iehthyophis } \\
\text { glutinosus }\end{array}$ & $\begin{array}{l}\text { No spermatogonia traceable to primordial germ } \\
\text { cells; arise from epithelium of collecting tu- } \\
\text { bules. }\end{array}$ \\
\hline Nieuwkoor & 1946 & $\begin{array}{l}\text { Triton and } \\
\text { Ambystoma } \\
\text { mexicanum }\end{array}$ & $\begin{array}{l}\text { Germ cells differentiate in the lateral plate of } \\
\text { presumptive mesoderm. }\end{array}$ \\
\hline \multicolumn{4}{|c|}{ Reptiles } \\
\hline Allen & 1906 & $\begin{array}{l}\text { Chrysemys } \\
\text { marginata }\end{array}$ & $\begin{array}{l}\text { Germ cells are early segregated cells first seen } \\
\text { in the entoderm. }\end{array}$ \\
\hline Jarvio & 1908 & $\begin{array}{l}\text { Phrynosoma } \\
\text { cornutum }\end{array}$ & $\begin{array}{l}\text { Germ cells from early segregated cells appear } \\
\text { first in the entoderm. }\end{array}$ \\
\hline Dustin & 1910 & $\begin{array}{l}\text { Chrysemys } \\
\text { marginata }\end{array}$ & $\begin{array}{l}\text { Primary germ cells from entoderm. Secondary } \\
\text { from epithelial cells. }\end{array}$ \\
\hline \multicolumn{2}{|c|}{$\underset{\text {-Gossler }}{\text { Von Berenberg }} \mathbf{1 9 1 4}$} & Lacerta agilis & $\begin{array}{l}\text { Germ cells from mesodermal cells. So-called } \\
\text { primordial cells are misnamed. }\end{array}$ \\
\hline
\end{tabular}


TABLE 1 (continued)

\begin{tabular}{|c|c|c|c|}
\hline AUTHOR & DATE & ANIMAL 1 & REMARKS ON GERM ORLLS \\
\hline \multicolumn{4}{|c|}{ Reptiles (continued). } \\
\hline Jordan & 1917 & Caretta caretta & $\begin{array}{l}\text { Primordial germ cells recognized in yolksac epi- } \\
\text { thelium. }\end{array}$ \\
\hline Simkins & 1925 & Trionyx & $\begin{array}{l}\text { No evidence to show an extraembryonie origin } \\
\text { for the primordial germ cells. }\end{array}$ \\
\hline \multirow[t]{2}{*}{ Risley } & 1933 & $\begin{array}{l}\text { Sternotherus } \\
\text { odoratus }\end{array}$ & $\begin{array}{l}\text { Germ cells from early differentiated cells. Defi- } \\
\text { nitive germ cells from primordial germ cells }\end{array}$ \\
\hline & 1934 & $\begin{array}{l}\text { Sternotherus } \\
\text { odoratus }\end{array}$ & and from coelomic epithelium. \\
\hline \multicolumn{4}{|c|}{ Birds } \\
\hline Waldeyer & 1870 & Chiek & $\begin{array}{l}\text { Ova from germinal epithelium, spermatogonia } \\
\text { derived from epithelium of Wolffian duct. }\end{array}$ \\
\hline Hoffmann & 1893 & 12 species & Germ cells are early segregated cells. \\
\hline Nussbaum & 1901 & Chick & Germ cells first seen in splanchnopleure. \\
\hline Rubasehkin & 1907 & $\begin{array}{l}\text { Chick } \\
\text { Duek }\end{array}$ & Germ cells are early segregated cells. \\
\hline Tsehaschkin & 1910 & Chick & Germ cells are early segregated cells. \\
\hline \multicolumn{2}{|c|}{$\begin{array}{l}\text { Von Berenberg } \\
\text {-Gossler } \quad 1912\end{array}$} & Chick & $\begin{array}{l}\text { So-called primordial cells seen in splanchno- } \\
\text { pleure are not germ cells. }\end{array}$ \\
\hline Swift & $\begin{array}{l}1914 \\
1916\end{array}$ & Chick & $\begin{array}{l}\text { Germ cells first seen in proamnionie region are } \\
\text { entoderm in origin. }\end{array}$ \\
\hline Firket & $\begin{array}{l}1914 \\
1920 a\end{array}$ & Chick & $\begin{array}{l}\text { Germ cells primarily from germinal epithelium } \\
\text { possibly from primordial germ cells. }\end{array}$ \\
\hline Goldsmith & $\begin{array}{l}1928 \\
1935\end{array}$ & Chick & $\begin{array}{l}\text { Germ cells arise in an extraembryonic position } \\
\text { and give rise to definitive sexual elements. }\end{array}$ \\
\hline Dantsehakoff & $1931 \mathrm{a}$ & Chick & $\begin{array}{l}\text { Primordial germ cells from entodermal wander- } \\
\text { ing cells. }\end{array}$ \\
\hline Blocker & 1933 & Sparrow & $\begin{array}{l}\text { Germ cells are early segregated cells first recog- } \\
\text { nized in proamnion. }\end{array}$ \\
\hline Witschi & 1935 & Sparrow & Germ cells first seen in yolksac splanchnopleure. \\
\hline \multicolumn{4}{|c|}{ Mammals } \\
\hline Allen & 1904 & $\begin{array}{l}\text { Pig } \\
\text { Rabbit }\end{array}$ & Functional germ cells from peritoneal cells. \\
\hline Rubaschkin & $\begin{array}{l}1908 \\
1909 \\
1912\end{array}$ & $\begin{array}{l}\text { Cat, Rabbit } \\
\text { Mole } \\
\text { Guinea pig } \\
\text { Porpoise }\end{array}$ & $\begin{array}{l}\text { Early segregation of primordial germ cells; } \\
\text { located in entoderm and give rise to definitive } \\
\text { sex cells. }\end{array}$ \\
\hline Sainmont & 1906 & Cat & $\begin{array}{l}\text { Primordial germ cells (ova) present but not } \\
\text { functional. Functional cells arise from epithe- } \\
\text { lium or peritoneum. }\end{array}$ \\
\hline
\end{tabular}


TABLE 1 (continued)

\begin{tabular}{|c|c|c|c|}
\hline AVTHOR & DATE & ANIMAL ${ }^{1}$ & REMARKS ON GRRM CELLS \\
\hline \multicolumn{4}{|c|}{ Mlammals (continued) } \\
\hline $\begin{array}{l}\text { Winiwarter } \\
\text { and } \\
\text { Sainmont }\end{array}$ & 1909 & Cat & Definitive germ cells from germinal epithelium. \\
\hline Kingsbury & 1913 & Cat & $\begin{array}{l}\text { Germ cells proliferated from germinal epithe- } \\
\text { lium. }\end{array}$ \\
\hline Kirkham & 1916 & Mouse & $\begin{array}{l}\text { Oogonia from primordial cells, spermatogonia } \\
\text { from epithelial cells. }\end{array}$ \\
\hline Vannemann & 1917 & Armadillo & Germ cells first seen in entoderm of blastocyst. \\
\hline Kingery & 1917 & Mouse & Ova from germinal epithelium. \\
\hline Firket & $1920 \mathrm{~b}$ & Albino rat & $\begin{array}{l}\text { Early primordial germ cells degenerate, not } \\
\text { progenitors of definitive sex cells. }\end{array}$ \\
\hline Hargitt & 1925 & Rat & Germ cells from germinal epithelium. \\
\hline $\begin{array}{l}\text { Cowperth- } \\
\text { waite }\end{array}$ & 1925 & Rat & $\begin{array}{l}\text { No origin of germ cells from germinal epithe- } \\
\text { lium. }\end{array}$ \\
\hline Buteher & 1927 & White rat & $\begin{array}{l}\text { Primordial germ cells degenerate, definitive sex } \\
\text { cells from germinal epithelium. }\end{array}$ \\
\hline Brambell & 1927 & Mouse & Ova from germinal epithelium. \\
\hline Heys & 1931 & Albino rat & Germ cells are early segregated cells. \\
\hline da Costa & 1932 & Guinea pig & $\begin{array}{l}\text { Primordial germ cells first seen in allantoic } \\
\text { mesoblast. }\end{array}$ \\
\hline Politzer & 1933 & Man & $\begin{array}{l}\text { Germ cells first seen in yolksac entoderm of pre- } \\
\text { somite embryo. }\end{array}$ \\
\hline Hamlett & 1935 & Man & Germ cells occur in midgut, not found elsewhere. \\
\hline Bookhout & 1937 & Guinea pig & $\begin{array}{l}\text { Early primordial cells degenerate, not ancestors } \\
\text { of definitive sex cells. }\end{array}$ \\
\hline Trabueco & 1938 & Rabbit & $\begin{array}{l}\text { Germ cells located in 7-day embryo. Early dif- } \\
\text { ferentiated cells. }\end{array}$ \\
\hline Kingsbury & 1938 & Cat & $\begin{array}{l}\text { No functional ova from germinal epithelium, } \\
\text { all from primordial germ cells. }\end{array}$ \\
\hline \multirow[t]{2}{*}{ Everett } & 1942 & Opossum & Germ cells from germinal epithelium. \\
\hline & 1943 & Mouse & $\begin{array}{l}\text { Primordial germ cells are set aside early in de- } \\
\text { velopment, first seen in entoderm. }\end{array}$ \\
\hline Witschi & 1948 & Man & $\begin{array}{l}\text { Primordial sex cells first found in yolksac and } \\
\text { allantoic extension of yolksac. }\end{array}$ \\
\hline
\end{tabular}

Technical names are those given by authors. 
shown that these several characteristics may vary with the species studied, with the type of fixation and stain used, and even with the physiological state of the germ cells at the time of fixation.

In the largemouth black bass the germ cells may be recognized by their large size (figs. 10,13, 16, 20), granular cytoplasm, definite nuclear and cellular outlines (figs. 9, 13, 16, 19, 23), capacity for independent movement (fig. 13), presence of an attraction sphere during certain phases of their migration (figs. 11, 14, 15, 20), and by the diffuse arrangement of the chromatin in their nuclei as compared to that of somatic cells (figs. 14, 20). No primordial germ cells were observed to possess yolk granules, a feature which agrees with the findings of Dodds ('10), who also failed to observe yolk granules in the primordial cells of Lophius. Dodds ('10, p. 579) marks that:

"The germ cells of most vertebrates so far studied are up to quite a late stage filled with deeply staining yolk spherules which cause them to stand out prominently among the surrounding cells. In my preparations, they are marked in no such conspicuous manner."

\section{Size of the germ cells}

In the largemouth black bass the germ cells vary in size in the various embryos and larvae. Their size was determined in a series of embryos, larvae and fry ranging from embryos 32 -hours in age to fry $13-\mathrm{mm}$ in length. Measurements were made with a calibrated ocular micrometer under oil immersion at a magnification of 1350 diameters. These measurements were averaged for each embryo, larva and fry (table 2). The number of measurements made in each developmental stage is given in parentheses (table 2).

The size of the germ cells was least variable in the 44-hour embryo and was most variable in the 11- and 13-mm fry. The germ cells were most nearly spherical in the 44-hour embryo and were least nearly spherical in the 42 -hour embryo. The elliptical form encountered in the germ cells of the 42-hour 
embryo may be attributed to the fact that at that time they were migrating from the subintestinal yolksac extension into the splanchnic mesoderm below the gut (figs. 11-14).

Mention must be made of the size differences between the primordial germ cells and the cells with which they are most confused, the hemocytoblasts (primitive blood cells). Figure 18 is a photomicrograph of a cross section through the yolksac extensison of a 45-hour embryo from which its membranes were removed. During manipulation the ventral mesentery was slightly torn but general relationships are still apparent.

TABLE 2

Table of average measurements of germ cells in microns, $\times 1350$

\begin{tabular}{|c|c|c|}
\hline \multicolumn{2}{|c|}{ STAGE OF DEVTLOPMRENT } & AVERAGE SIZE IN MICRONS \\
\hline 37-hr. embryo & $(9)$ & $12.451 \times 13.003$ \\
\hline 42-hr. embryo & (12) & $10.86 \times 14.245$ \\
\hline 44-hr. embryo & (15) & $12.10 \times 12.32$ \\
\hline 47-hr. embryo & $(10)$ & $11.13 \times 13.44$ \\
\hline 4.5-mm larva & $(10)$ & $11.09 \times 13.45$ \\
\hline 11- and $13 \cdot \mathrm{mm}$ fry & (8) & $11.17 \times 13.72$ \\
\hline
\end{tabular}

Here a germ cell and a cell identified as a hemocytoblast are seen lying side by side. The hemocytoblast is identical with those found in the primitive blood vessels. In an enlargement of the two cells (fig. 19), the attraction sphere of the germ cell is clearly shown. The granular cytoplasm of the primordial cell appears as a "cap" surrounding the nucleus. This cell is about 3.6 times as large as the hemocytoblast. By actual measurement the ratio of the volume of the nucelus to that of the cytosome is $9: 4$ for the hemocytoblast and $33: 9$ for the primordial germ cell. The nucleus of the hemocytoblast is relatively greater in volume as compared to the total volume of the cell than is that of the primordial germ cell. 


\section{The number of primordial germ cells}

A question that usually arises in an investigation of the germ cell history is that of the number of primordial germ cells. In the present study the germ cells were counted and their position relative to the gut and the pronephric ducts were recorded for a series of embryos, larvae and fry ranging from the 37-hour stage to the 13-mm stage. Extreme care was exercised to obtain accurate counts. This was facilitated by the size of the germ cells themselves, in that they usually did not extend through more than two sections $10 \mu$ in thickness. The section containing the maximum portion of the nucleus arbitrarily was recorded as the one in which the germ cell was located.

The number of primordial germ cells was found to vary from individual to individual and from series to series of collections. As few as 21 were counted in a 37-hour embryo and as many as 105 in a 13-mm fry. The low number obtained in the 37-hour embryo undoubtedly should be attributed to difficulty of recognition, since as embryonic and larval development progressed recognition of the germ cells became increasingly easier. It is logical to assume that the increase in number was due to division of the germ cells. A careful study of the early developmental stages was made but in none of them was a germ cell seen to be dividing.

The usual relationship of the germ cells to the gut and the pronephric ducts in a 3.5-mm larva is shown in table 3. The total number of germ cells recorded for this individual is 61 , about the average number for larvae of this length. The number of sections, $10-\mu$ thick, cranial to the anus, in which germ cells were found is noted in the left hand column. The number of germ cells in each section is recorded in the center column and their positions relative to the gut and pronephric ducts are recorded in the right hand column.

While counting the germ cells it was observed that in $3.5-\mathrm{mm}$ larvae they were concentrated near the midline and were restricted to an area beginning with the 8th section craniad 
of the anus and continuing craniad through the 36th section. In 5.5- to $6.5-\mathrm{mm}$ larvae the germ cells were distributed laterally, in the region ventral and ventrolateral to the pronephric ducts. In larvae of this length, the germ cells were restricted to an area beginning with the 18th section craniad of the anus and extending through the 48 th section. Figure 4 is a graphic

TABI.E 8

Germ cell count in a prehatching embryo $3.5 \mathrm{~mm}$ in length, 46 to 47 hours of age

\begin{tabular}{|c|c|c|}
\hline $\begin{array}{l}\text { SECTION CRANIAL } \\
\text { OF ANUS }\end{array}$ & $\begin{array}{l}\text { NUMBGR OF } \\
\text { GERM CELLS }\end{array}$ & RELATIVE LOCATION \\
\hline 8 & 1 & In yolksac extension ventral to gut. \\
\hline 9 & 0 & \\
\hline 10 & 1 & Ventrolateral to gut. \\
\hline 11 & 0 & \\
\hline 12 & 0 & \\
\hline 13 & 2 & $\begin{array}{l}1 \text { dorsomedial to gut, } 1 \text { dorsolateral } \\
\text { to gut. }\end{array}$ \\
\hline 14 & 6 & Dorsal to gut. \\
\hline 15 & 7 & Dorsolateral and medial to gut. \\
\hline 16 & 7 & Dorsolateral and medial to gut. \\
\hline 17 & 5 & Dorsomedial to gut. \\
\hline 18 & 3 & Dorsal to gut. \\
\hline 19 & 3 & Dorsal to gut. \\
\hline 20 & 6 & $\begin{array}{l}4 \text { dorsal, } 1 \text { lateral, } 1 \text { dorsolateral to } \\
\text { gut. }\end{array}$ \\
\hline 21 & 1 & Dorsal to gut. \\
\hline 22 & 1 & Dorsal to gut. \\
\hline 23 & 1 & Dorsal to gut. \\
\hline 24 & 1 & Dorsal to gut. \\
\hline 25 & 2 & Dorsal to gut. \\
\hline 26 & 0 & \\
\hline 27 & 1 & Ventral to left pronephrie duet. \\
\hline 28 & 1 & Ventral to left pronephric duct. \\
\hline 29 & 2 & Dorsomedial to gut. \\
\hline 30 & 0 & \\
\hline 31 & 4 & Dorsomedial to gut. \\
\hline 32 & 1 & Dorsal to gut. \\
\hline 33 & 1 & Dorsal to gut. \\
\hline 34 & 3 & Dorsomedial to gut. \\
\hline 35 & 0 & \\
\hline 36 & 1 & Dorsomedial to gut. \\
\hline & 61 & \\
\hline
\end{tabular}


representation of the lateral and cranial shifting of the germ cells. In this figure, the midline of the larvae is designated by the solid center line of the graph. The graph is thus divided into right and left portions corresponding to the right and left sides of the larvae. The positions of the germ cells relative to the gut and pronephric ducts are plotted along the vertical axis and the number of sections anterior to the anus is represented on the horizontal axis. The solid circles represent germ cells of $3.5-\mathrm{mm}$ larvae, and the open circles represent those of 5.5- to $6.5-\mathrm{mm}$ larvae. In $3.5-\mathrm{mm}$ larvae the first germ cell was found in the 8th section anterior to the anus. With the exception of those in sections 12, 15, 16, 27 , and 28 , the majority of the cells were situated near the midline or slightly lateral to it. In 5.5- to $6.5-\mathrm{mm}$ larvae the most posterior germ cell was found in the 18th section anterior to the anus and was situated near the midline. Farther craniad, however, the germ cells were observed to lie more and more lateral in position and were situated in the region of the definitive gonad, ventral or ventrolateral to the pronephric ducts. From this graph it may be noted that the germinal area of $3.5-\mathrm{mm}$ larvae extends through 28 sections or $280-\mu$, whereas, that of $5.5-$ to $6.5-\mathrm{mm}$ larvae extends through 30 sections or $300-\mu$. The relative lengths of the germinal area is about the same for the two length larvae, except that in the 5.5- to 6.5-mm one it has shifted about $100-\mu$ farther forward from the anus. This shift of the germinal area in the 5.5- to $6.5-\mathrm{mm}$ larvae may be attributed in part to a migration craniad of the germ cells themselves and in part to a lengthening of that portion of the hindgut posterior to the germinal area.

\section{History of the germ cells}

A. General consideration. The history of the germ cells in the largemouth black bass may be divided into two primary stages each of which may be subdivided into periods and phases (table 4). These several divisions may be correlated, furthermore, with various life history stages (table 4). 
$B$. Premigration period. In an embryo of 16 - to 18-hours of development, about the time of blastopore closure, an excrescence of large cells was observed in the region of the dorsal lip of the blastopore (figs. 1, 5, 6). A careful study of sagittal serial sections revealed that these cells, or at least some of them make their way into the embryo between the mesentoderm and the periblast (figs 2,6 ). I believe these cells are the forerunners of the primordial germ cells seen later in the periblast below Küpffer's vesicle (fig 9). This belief is supported by the fact that their size is comparable to that of cells positively identified as germ cells. If this interpretation

TABLE 4

The history of the germ cells in the largemouth black bass

\begin{tabular}{|c|c|}
\hline DEVELOPMENTAL STAGE & DIVISION OF GERM CELL HISTORY \\
\hline Blastoderm to $6.5 \mathrm{~mm}$ & Pregonadal stage \\
\hline Blastoderm to 32 lirs. & $\begin{array}{l}\text { Premigration period including locus of earliest } \\
\text { recognition }\end{array}$ \\
\hline 32 hrs. to $6.5 \mathrm{~mm}$ & Migration period \\
\hline 32 hrs. to $47 \mathrm{hrs}$. & Yolksae extension phase \\
\hline $37 \mathrm{hrs}$. to $4.0 \mathrm{~mm}$ & Splanehnopleure phase \\
\hline $3.5 \mathrm{~mm}$ to $6.5 \mathrm{~mm}$ & Retroperitoneal phase \\
\hline $6.0 \mathrm{~mm}$ to adult & Gonadal stage \\
\hline $6.0 \mathrm{~mm}$ to $3.0 \mathrm{em}$ & Germ gland formation period \\
\hline $20.0 \mathrm{~mm}$ to $3.0 \mathrm{~cm}$ & The indifferent period \\
\hline $3.0 \mathrm{~cm}$ to $4.5 \mathrm{~cm}$ & Sex differentiation period \\
\hline
\end{tabular}

is correct, this excrescence represents the earliest stage at which I have been able to identify the germ cells in this species. Here they seem to be definitely segregated and set aside for a future migration into the embryo.

In an embryo of 22-hours of development cells similar to those in the dorsal excrescence were observed in the periblast in the vicinity of Küpffer's vesicle (fig. 9). These cells in the periblast measured approximately 12.0 by $12.5 \mu$. In later stages of development they come to lie in the caudal extension of the yolksac. It appears that as the tail differentiates and lengthens a subintestinal extension of the yolksac 


\section{EXPLANATION OF FIGURES}

Text figures 1-4 are line drawings; figures 5-52 are unretouched photomicrographs.

\section{LIST OF ABBREVIATIONS}

\begin{tabular}{|c|c|}
\hline coe, coelom & pge, potential primordial germ cell \\
\hline exc, excrescence & pnd, pronephric duet \\
\hline dl bp, dorsal lip of the blastopore & sb, swimbladder \\
\hline dm, dorsal mesentery & siv, subintestinal vein \\
\hline ge, germ cell & te, testocoel \\
\hline gs, genital sinus & $t d$, testicular duet \\
\hline kv, Küpffer's vesiele & ub, urinary bladder \\
\hline ls, lymph space & vm, ventral mesentery \\
\hline mes, mesovarium & $\mathbf{v v}$, vitelline vein \\
\hline $\begin{array}{l}\text { ove, ovocoel } \\
\text { pbn, periblast nucleus (i) }\end{array}$ & yse, yolksac extension \\
\hline
\end{tabular}

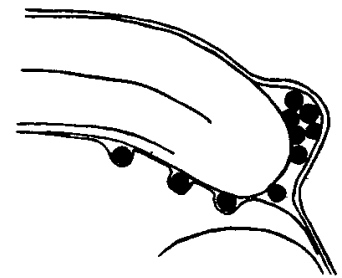

Fig. 1 A diagram showing the relationship of the dorsal lip exerescence of potential germ cells. The germ cells are represented by black dots and are shown passing from the excrescence into the periblast ventral to the dorsal lip of the blastopore.

is carried back, with the result that the germ cells are shifted caudad. In embryos of 32-hours of development the germ cells are situated dorsally in the subintestinal yolksac extension (figs. 3, 7, 10). They possess a definite outline, granular cytoplasm, and measure approximately 12.5 by $13.0 \mu$. The migration of these cells from this extension of the yolksac is described in the following section.

C. Migration period. The first phase of migration, the yolksac extension phase, was observed in embryos of 37-hours of development. At this stage the germ cells were observed in apparent migration from the subintestinal yolksac extension into the mesoderm ventral to the gut. Figure 11, a transverse section through a 37 -hour embryo at the level of junction of 
the yolksac with its caudal extension, shows two germ cells believed to be in migration. One is located in the dorsal portion of the yolksac extension and is passing into the mesoderm ventral to the gut. The other has completed its passage and is lodged in the splanchnic mesoderm dextroventral to the gut. It is significant that the germ cells do not enter the gut entoderm, nor are they immediately associated with it. The impression is gained that the lowermost cell is apparently dissolving the mesodermal cell against which it is resting. It would appear that the germ cells possess some cytolytic property which enables them to pass through layers and masses of cells. However, they may merely wedge their way between

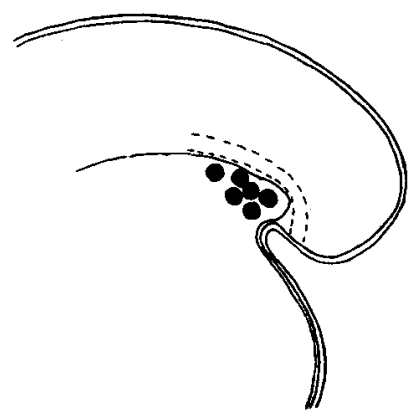

Fig. 2 A diagram showing the early relationship of the germ cells (black dots) to the caudal yolksae extension. The broken line represents the definitive position of the gut.

the mesodermal cells. Each primordial germ cell possesses a centrosphere in the trailing side of the cytoplasm.

This first migration phase continues for several hours (table 4). A section of a 41-hour embryo, taken at the same level as figure 11, shows two germ cells in the mesentery ventral and to the left of the gut (fig. 8). The characteristic diffuse arrangement of the chromatin in the nucleus and the granular condition of the cytoplasm are evident. Convincing evidence of an amoeboid movement was observed in 44-hour embryos. In figure 12 a germ cell is seen projecting into the cavity of the yolksac extension ventral to the left pronephric duct. This cell is on its way from the extension into the 
mesentery above. A higher magnification of the pronephric duct region reveals that the germ cell possesses a blunt pseudopodial extension which projects into the mesoderm above (fig. 13).

In other 44-hour embryos the germ cells have migrated into the mesoderm ventral to the gut and are located to the right and the left of it. In figure 14, the difference between the nuclei of the germ cells and those of the somatic cells of the gut and surrounding tissue are clearly demonstrated. In a section somewhat posterior to that represented in figure 14, a germ cell is seen in the dorsal part of the cavity of the yolksac extension just ventral to the right pronephric duct. The definiteness of its cellular outline and the presence of an attraction sphere to the right of the nucleus should be noted (fig. 15). Sections taken further caudad show that the germ cells lie in the mesentery ventral to the gut. In figure 16, representing a section almost at the posterior end of the yolksac extension, a germ cell occupies a position in the mesentery dextroventrolateral to the gut. Its outline is very definite and the cell stands out conspicuously among the flattened cells of the mesentery. It appears that the germ cells are capable of retaining their definite outlines even when surrounded by other tissue cells. This quality is retained throughout their history.

Figure 3 represents diagrammatically the path of migration taken by the germ cells. The germ cells are indicated by black dots and are shown passing from the yolksac extension into the mesoderm ventral to the gut and then dorsad around the gut through the splanchnic mesoderm to the dorsal mesentery. This ends the first phase of migration.

The second phase of migration begins when the germ cells have entered the splanchnic mesoderm. In embryos of near hatching age, the germ cells were observed in the process of migration dorsad in the splanchnic mesoderm around the gut and are to be found in various positions in it. In embryos of this age the gut is a well-formed tube consisting of a single epithelial layer with an indiscrete basement membrane. A 
transverse section through the hindgut region of a 47-hour laboratory hatched embryo shows two germ cells lying in the mesoderm (fig. 21). In other 3.5-mm lravae (47-hours of development) the germ cells are found in the splanchnic mesoderm ventral and ventrolateral to the gut. Their outlines are very distinct even though completely surrounded by mesenteric cells (fig. 23). The section represented in figure 23 is taken posterior to that shown in figure 17 and is completely posterior to the yolksac extension. In this section 4 germ cells are present in the splanchnic mesoderm, two ventral to each pronephric duct. The basement membrane of the gut



Fig. 3 A diagram showing the later relationship of the germ cells (black dots) to the yolksac extension. The germ cells are shown passing out of the extension into the mesoderm ventral to the gut and then dorsad to the dorsal mesentery. The broken lines represent the right pronephric duct (pnd). The pronephrie duets are shown entering the gut near the anus. The subintestinal vein (siv) is shown passing sinistroventrad around the gut and continuing anteriad as the vitelline vein (vv) beneath the yolk.

is very definite and it is clear that the germ cells are not located in the entoderm. Careful observation discloses that flattened mesodermal cells are present between the germ cells and the gut. The germ cells seem to be interposed between the layers of coelomic mesoderm. Thus, it appears that the germ cells are following the potential coelomic cavity as a route of migration.

In 4.0-mm larvae the germ cells lie in the mesentery dorsal to the gut (fig. 25). Larvae of this length are one to two days old and move about by vigorous lashings of the tail. Most of the changes which have occurred between the 3.5- and 
4.0-mm larvae are internal, involving the yolksac and the gut. The midgut is slightly curved to the left and the liver is beginning to form between the yolksac and the body wall. The coelom is beginning to form in the posterior trunk region.

Sections through the hindgut region of a $4.0-\mathrm{mm}$ larva show that the germ cells are situated in the dorsal mesentery near the crest of the gut (fig. 25). Even at this early stage the germ cells are retroperitoneal and are ready to begin their third phase of migration. This relationship is better seen in 4.5- and 5.5-mm larvae. Sections of the hindgut of larvae of this length, two days after hatching, show that the germ cells now lie above the peritoneum. In figure 27 , a section through the hindgut of a $5.0-\mathrm{mm}$ larva, three germ cells lie ventral to the pronephric ducts, two on the right and one on the left. Considerable change has taken place in the gut and coelom as compared to the condition found in the $3.5-\mathrm{mm}$ larvae. The coelomic spaces are well defined and the gut epithelium has assumed a columnar arrangement. The dorsal mesentery is relatively much thinner than before and there is some evidence of the formation of vascular channels.

The third migration phase, the retroperitoneal phase, was observed to begin in 5.5- to $6.5-\mathrm{mm}$ larvae, three to 5 days after hatching. In the retroperitoneal phase the germ cells shift laterally from a concentration along the midline to a position ventral and ventrolateral to the pronephric ducts. In figure 28 , a section of the hindgut of a $6.5-\mathrm{mm}$ larva, 4 germ cells are represented. Two lie ventral to each of the pronephric ducts, slightly to the right and to the left of the dorsal mesenteric limbs. The epithelium of the gut has been thrown into four major folds, two of which show in this section. In sections further craniad the germ cells are situated in a more lateral position and have reached the site of the future gonad (fig. 29). This migration phase is demonstrated graphically by figure 4 .

D. Gonad formation. The condition of the germ cells in the 6.5- to 7.5-mm fry is much the same as that found in the 





5.0-mm larvae. In the $8.0-\mathrm{mm}$ fry, however, the gonad begins to differentiate.

After reaching the gonad site, the germ cells, now primary gonia, are invested with mesenchymal cells derived from the peritoneum and subjacent mesenchyme. The gonad, thus formed, consists of a line of single gonia surrounded by a thinly stretched epithelium (fig. 32). The one-layered condition of this epithelium apparently is changed to that of a two-layered one by proliferation of cells already present in the epithelium and further investment by mesenchymal cells (fig. 33).

Cross sections of the gonad of an 11-mm fry show that the gonad consists of gonia covered by two layers of epithelial cells (fig. 34). Because of subsequent events, the inner layer of this epithelium may be interpreted as a follicular layer and the outer as a true epithelial layer (fig. 36). In sections anterior to that shown in figure 34, the gonad is suspended in the coelom by a delicate mesentery derived from the peritoneum and in cross section, has the appearance of a shorthandled club (fig. 35).

In 11- and 13-mm fry the gonad begins to grow through increase in size and number of the gonia. Fry of this length are 10 to 12 days old, swim freely, and are quite bass-like. The gut possesses two or three coils and ends in the straight hindgut. The urinary bladder is beginning to form as an evagination from the joined mesonephric ducts and lies dorsal to the gut and dorsal mesentery, retroperitoneally. The swimbladder has grown caudad dorsal to the gonads which now are suspended from its ventral surface as in the adult.

From time to time new gonia are added to those already present so that cysts of gonia are formed (fig. 31). This increase in number may be attributed to division, but since no mitoses have been observed it is possible that the increase is due to a continued anteriad migration. The gonad of 11- to $13-\mathrm{mm}$ fry is not a continuous strand of germ cells but is composed of discontinuous aggregations with intervening spaces. In gross appearance the gonad resembles a chain of 
beads. Subsequently, these spaces are filled and in the $20-\mathrm{mm}$ stage the gonad has become a rather solid strand. Gonocoel formation is instituted by the separation of the epitheilial layers of the gonad, leaving the germ cells contained within the, epithelial layer which lies on the mesenteric side (fig. 36). About the time that gonocoel formation begins, the blood supply to the gonad is established and circulation of blood is indicated by the presence of numerous blood cells in the gonadal vessel located in the mesentery. Fry-fingerlings 20-mm in length are approximately 25 to 30 days old, and have attained the major characteristics of the species.

\section{Sex differentiation}

A. The indifferent gonad. Between the $20-\mathrm{mm}$ stage and the $3-\mathrm{cm}$ stage the gonads, while potentially male or female, pass through an indifferent period. During this period there is a marked increase in their size, brought about by an increase in the stroma and by multiplication of the germ cells. The gonads, however, are predominantly stromal in composition. The gonocoel undergoes considerable enlargement and becomes more or less S-shaped, indicating differential growth in certain portions of its walls (fig. 37). In some regions the gonia are in division while in others they are in an interphase. An anteroposterior gradation of development is discernible during this period. Somewhat later, sex becomes microscopically recognizable. This condition will be discussed in the section devoted to the development of the ovary and the testis.

$B$. Development of the ovary. Sex is first microscopically distinguishable in the gonads of fingerlings of $3-\mathrm{cm}$ in length. In females of this size some of the gonia transform into oocytes and undergo growth. Coincident with the growth of the oocytes there is a marked increase in the amount of stroma in the gonad, resulting in the formation of tunica ovarii several layers in thickness (fig. 38). The mesovarium is quite broad and contains near its base both an artery and a vein. The gonocoel, now properly termed an ovocoel, is 
irregular in outline and is lined with squamous epithelium. A study of serial sections reveals that the ovocoels of the two ovaries fuse posteriorly to form a common sinus which continues into the dorsal mesentery of the hindgut as a median oviduct (figs. 39,40,41). When traced forward, the ovocoels end blindly within the ovaries.

In the ovaries of the more mature fish of $3.5-\mathrm{cm}$ in length, the oocytes occur singly or in follicular-like cysts surrounded by a single layer of stromal cells. The oocytes are contained within lamella of stroma which project into the ovocoel (fig. 42). Transverse and longitudinal sections of the ovary reveal that oocyte formation is most highly developed in the middle third of the ovary. The oocytes in fish $3.5-\mathrm{cm}$ long are two to three times as large as those in fish 3 -cm long and show the beginnings of primary yolk formation (fig. 44). In certain oocytes in more advanced stages of growth a light area of cytoplasm occurs directly around the nucleus surrounded by a darker peripheral area where yolk formation has begun (fig. 44).

In the 4.5-cm stage the sexes are distinguishable in gross dissection (fig. 50). Sections of the ovary at this stage reveal that certain oocytes appear to be growing more rapidly than others (fig. 43). In those oocytes undergoing rapid growth, the nucleus assumes a condition similar to that found in ripe ova. The chromatin loses its reticular structure and is broken up into numerous rounded bodies arranged peripherally along the nuclear membrane (fig. 43). This arrangement is probably significant in connection with yolk formation. In addition to oocytes in advanced stages of growth, numerous smaller oocytes and even oogonia are present (fig. 43).

In fingerlings $6.0-$ to $8.0-\mathrm{cm}$ in length the ovaries appear as distended elongate bodies located posteriorly in the coelom (fig. 51). Sections of ovaries at this time reveal secondary yolk formation in certain of the larger oocytes. This is indicated by the formation of vacuoles in the darker peripheral cytoplasm. The later history of the egg has not been followed in this investigation. 
C. Development of the testis. The organization of the testis apparently proceeds at a slower rate than does that of the ovary and not until the $4.0-\mathrm{cm}$ stage is reached does its differentiation become recognizable. The testis of fingerlings of this length bears little resemblance to that of older fish. The early testis differs structurally from the early ovary in the size of the gonocoel, the size of the gonia (spermatogonia), and in the relative amount of stroma present. The gonocoel, now properly termed the testocoel, is much smaller than that found in the early ovary and is lined with a low, irregular cuboidal epithelium instead of a squamous epithelium as is the ovocoel. The testis is predominantly germinal in composition. It lacks the thickened tunic which covers the ovary and is suspended in the coelom by a delicate mesorchium (fig. 45). No germ cells are in the epithelium, but they lie in the subjacent stroma and deeper in the gonad. Some of the germ cells occur in clusters and others occur singly, but all are surrounded by stromal cells. Most of the spermatogonia are similar in size but occasionally one is found that is slightly larger than the others. Whether these occasional ones are enlarged spermatogonia or are aberrant oocytes has not been determined. Some of the germ cells appear to be radially arranged around a potential lumen. The testis of this and later stages of development (fig. 52) exhibits an anteroposterior gradation in development, being more highly developed posteriorly. A clue to tubule formation, which occurs in this species, is obtained from scetions taken posterior to that shown in figure 45. The testocoel gives off numerous branches which penetrate the stroma between the germ cells so that they come to lie around them (fig. 46). Since these branches project in all directions and take tortuous paths, cross sections of them are obtained in any plane. This may explain the radial disposition of the germ cells described earlier. Morphologically the testocoel would correspond to a primary collecting duct and its branches to secondary and tertiary collecting ducts. 
In the 5.0- to 6.5-cm stage the testis has reached a definite tubular organization and is enlarged and dorsoventrally flattened (fig. 47). The germ cells are located in the walls of the tubules, occur singly, and are separated by stromal cells (fig. 49). The tubules consist, then, of both spermatogonia and supporting stromal cells. The germ cells appear to lie in but not to form the epithelium of the tubules (fig. 49). The epithelium of the tubule is derived from the testocoel, and each tubule is delimited by a connective tissue layer of stromal cells. In this as in the preceding stage, most of the spermatogonia are of approximately the same size. The testis at this stage also shows an anteroposterior gradation in development and is more highly organized posteriorly, as sections taken through this portion show more advanced tubule formation (fig. 48). The primary collecting duct lies near the mesial side of the testis (fig. 48) and fuses posteriorly with that from the other testis to form a common duct, the vas deferens.

For an account of further changes which occur in the ovary and testis prior to and during a seasonal cycle, reference should be made to a recent paper by James ('46).

\section{DISCUSSION}

Segregation of the germ cells

It is generally agreed that the germ cells retain certain generalized characteristics or properties which serve to distinguish them from somatic cells.

Eigenmann (1891), from work on Micrometrus, believed the germ cells to be primitive cells because he could trace them back into early stages of development, probably to the 5 th or 6th cleavage. The works of Wheeler (1899), Beard ('00-'02), Woods ('02), Fedorow ('07), Allen ('11a), Dodds ('10), Bachmann ('14), Okkelberg ('21), Richards and Thompson ('21), Hann ('27), Goodrich et al. ('34), Maschkowziff ('34), Bennington ('36), Dildine ('36), Moore ('37), and others all point to an early segregation and to a more or 
less primitive or embryonic condition of the primordial germ cells. Some investigators have found no morphological basis on which to pass judgement and contend that the difference between somatic and primordial germ cells is physiological. Others have been influenced by certain physical characteristics and believe that the primordial germ cells are undifferentiated. Among these characteristics are their yolk spherules and their capacity for independent movement. Still others believe that the primordial germ cells are undifferentiated because they possess an attraction sphere or because of their locus in the embryo.

Dodds ('10) found that there was an extrusion of plasmosomal material from the nucleus in the early germ cells and for this reason concluded that they were less primitive than the somatic cells in which such extrusions were not noted. Jordan ('17), in describing the cells of the germinal area in the loggerhead turtle, said that they represented a low grade of differentiation from cells of the blastoderm, inferring that they are undifferentiated cells. Because the germ cells remain unchanged for a long period of time whereas the somatic cells become smaller, lose their yolk and are organized into tissues, Okkelberg ('21) thought that the germ cells retain certain embryonic characteristics which serve to distinguish them from somatic cells.

The primordial germ cells of Micropterus salmoides salmoides are recognizable early in development, and, on the same basis that others have judged the primordial cells in various forms to be embryonic they also may be classed as undifferentiated cells. They are large in size and possess a distinct attraction sphere during certain phases of their history, are capable of independent movement, and are able to retain their cellular outlines when in contact with other cells, a property often lost by somatic cells. They do not possess yolk spherules but this lack is accounted for by the fact that in the bass the blastodisc alone cleaves and little or no yolk is included in the blastomeres.

The appearance of the excrescence at the dorsal lip of the blastopore, late in gastrulation, marks the time when the 
germ cells are first recognizable. However, this does not preclude the possibility that they may not have been segregated earlier. Although the manner of formation of the excresence was not determined, it appears to result from an unequal rate in the streaming movement of the cells during gastrulation causing a piling up of cells at the entrance to the blastopore. The position of the cells in the blastoderm with respect to the streaming movement might determine which are to become germ cells, though the accident of position could hardly be regarded as a determining factor. Not all of the cells of the excresence, but only those which succeed in making their way into the periblast beneath the dorsal lip, become germ cells. Those remaining outside apparently become incorporated in the caudal mass, since they remain surrounded by the epidermal stratum. It is only after a certain degree of differentiation in other cells has occurred that the primitive condition of the germ cells makes them conspicuous.

\section{Soma and germ cell relationships}

It has been shown that late in the embryonic development of vertebrates the germ cells come to lie in the coelomic epithelium covering the gonad, the germinal epithelium. This fact led to the concept that the primordial cells had developed from epithelial cells or were transformed stromal cells. Several students of this problem in fishes have found what they consider to be a transformation of stromal and epithelial cells into germ cells (Bohi, '04; Essenberg, '23; Van Oordt, '24; Foley, '27; Wolf, '31; Odum, '36). This concept also has been applied to many vertebrates other than fishes (table 1 ). Nevertheless, the following statement made by Beard ('02c, $p$. 691) on this subject, is still applicable:

"The change from epithelial cell into germ cell. though asserted times without number, has never really been depicted, and in all probability it has never actually been observed. Indeed, it does not exist."

A few investigators admit that either the fate of the primordial cells is doubtful, or that they give rise to one or the 
other of the sexual elements (table 1). It seems quite improbable, if not impossible, for definitive sex cells to be derived from primordial elements in one sex and from somatic elements in the other.

A germinal epithelium, in the sense that it has been described by various authors for certain reptiles, birds and mammals, is nonexistent in the bass. For this animal the term "germinal epithelium" has no significance other than to designate that particular portion of the coelomic epithelium which overlies the gonads. It has been shown that the primordial cells, after reaching the primordium of the gonad, remain as discrete elements and form no part of the epithelium. From the very beginning they lie above the epithelial cells of the coelom. No evidence of a transformation of stromal or epithelial cells into germ cells was observed to occur in either the testis or the ovary of the bass. Neither is there any indication of a degeneration of the primordial cells in either sex, as has been reported to occur in one or both sexes of some other fishes (Essenberg, '23; Van Oordt, '24; Wolf, '31; Odum, '36). Therefore, it would appear that the definitive sexual elements of both sexes arise only from the lineal descendants of primordial germ cells.

\section{Migration of the primordial germ cells}

Two of the most interesting features of the germ cell history are the path and mode of migration of the primordial germ cells. The path usually described for higher vertebrates leads from the gut entoderm into the splanchnic mesoderm, thence dorsad through the dorsal mesentery and laterad to the germ gland primordia. This same general path of migration has been observed to hold for some fishes, particularly those which develop from eggs that undergo holoblastic cleavage such as Amia, Lepisosteus, and Acipenser (Allen, '11a; Maschkowziff, '34). Notable variations among fishes also have been reported. It may be mentioned that in Lophius (Dodds, '10) and Lebistes (Dildine, '36) the germ cells are 
said to pass through the myotomes. Most investigators, however, have found that in fishes the path of migration of the primordial germ cells leads through one or both layers of the lateral plate mesoderm and not through the gut entoderm. One investigator, Wolf ('31), found that the primordial cells of Platypoecilus maculatus migrate through the somatic layer of mesoderm and pass mesiad into the gonad primordia.

The path taken by the primordial cells of Micropterus deviates not only from that usually described for the higher vertebrates but also from that usually reported for fishes. The early location of these cells in the caudal extension of the yolksac and their subsequent migration through and between the layers of coelomic mesoderm are unusual. A similar but probably not a homologous condition is found in the human embryo of 13 somites (Witschi, '48). Witschi found that the primordial germ cells could first be identified in the entoderm of the caudal allantoic extension of the yolksac. The similarity of this extension with the caudal extension of the yolksac in the bass is worthy of note (see fig. 1, Witschi, '48), though it seems improbable that these two yolksac extensions are homologues. The primordial cells of both the bass and of man actively migrate from the yolksac entoderm or the yolksac extension. Those of man pass into the splanchnopleure and gut entoderm, and those of the bass pass into and between the layers of coelomic mesoderm. If Witschi's ('48, p. 77) statement that:

"The gut endoderm is rather an obstacle than a center toward which free germ cells might direct movements"

is correct, then the condition found in the bass, wherein no germ cells become located in the gut entoderm, might represent a more basic vertebrate pattern than that found in man and other higher forms. According to Witschi ('48) those germ cells of man, and possibly other higher vertebrates, which occur in the gut epithelium get there quite accidentally, and as a result their migration is either retarded or stopped.

Three major theories have been advanced to account for the migration of primordial germ cells. The first of these 
is that cells migrate actively by amoeboid movement; the second is that they are passively carried along by shifting tissue masses, and the third is intravascular.

According to those who uphold the first theory, the primordial cells are capable of moving between other cells and through membranes. Beard ('00-'02, Allen ('11a), Bachmann ('14), Reinhard ('24), Wolf ('31), and Moore ('37), and others have described an active amoeboid migration of germ cells in fishes. This type of migration also has been described for other vertebrate forms by Allen ('06), Jordan ('17), Woodger ('25), Dantschakoff ('31a), Cheng ('32a), Risley ('33), Blocker ('33), Everett ('43), Witschi ('48), and others.

Those who support the second theory discount the possibility of an amoeboid migration, contending that it is improbable that the germ cells possess the ablity to migrate through tissue and to traverse distances of several millimeters in order to reach the germ gland primordia. Simkins ('32, p. 268), who supports the germinal epithelium theory, does not believe that the germ cells can:

"Set out on a journey over several millimeters of intervening tissue, cross barriers and penetrate membranes, become carried away in the blood stream, perishing against obstacles they cannot surmount, until the survivors are at last safe in the fundament of the genital gland."

In the human embryo the total distance traversed by the germ cells is not more than $0.5 \mathrm{~mm}$ (Witschi, ' 48 ). In mouse embryos, Everett ('43) found this distance to be not one or several millimeters but only a small fraction of a millimeter.

Some investigators think of the migration as being partly active and partly passive; or, as resulting from the normal processes of growth Dodds ('10), Okkelberg ('21), Richards and Thompson ('21), Hann ('27), and others. Richards and Thompson ('21) believe that the term "migration" is not appropriate and suggest the term "translocation" as a substitute. 
The third theory, or intravascular migration, has been described only in birds. Several investigators who have studied the problem of germ cell migration in these forms have either observed morphologically or demonstrated experimentally that the primordial cells actually enter or become entrapped in the vascular channels of the splanchnic mesoderm of the area vasculosa and are passively carried to the germ gland region (Swift, '41; Reagan, '16; Richards, Hulpieu and Goldsmith, '26 ; Goldsmith, '28; Dantschakoff et al., '31; Blocker, '33, Dantschakoff, ' 35 ; and others). All have observed that after circulating in the blood stream for some time the germ cells become lodged in the capillaries near the gonad primordia. Several theories have been advanced to account for this. The oldest of these is the chemotatic theory. According to its proponents (Swift, '14; Firket, '14; Reagan, '16), a chemotatic substance is elaborated by the gonadal primordia and attracts the germ cells. More recent workers however, believe that aggregation of the germ cells is the result of mechanical blockage of the small capillaries by the large turgid germ cells (Dantschakoff, '31a, b, '35, and Blocker, '33). Although they differ on the cause, all of these investigators agree that after the germ cells become lodged in the capillaries of the gonad region they assume active amoeboid movements, and by this means leave the blood vessels and migrate through the mesentery and adjacent areas to the gonad primordia. More recently Dantschakoff ('35) treated chick embryos with sublethal doses of $x$-ray and produced large phagocytic cells that were approximately the same diameter as primordial germ cells. She found that these cells acted in the same way as the primordial germ cells and ultimately came to rest in the gonads. She is of the opinion that the mechanical factors of size and consistency, together with reduced blood pressure, are primarily responsible for the retention of the germ cells in the capillaries of the gonad area.

As might be expected, not all of the cells identified as primordial germ cells reach the gonad primordia. In some forms the germs cells have been observed to take rather aber- 
rant courses in their migrations. Some get "lost" in the mesenchyme of the dorsal mesentery and in the splanchnopleure and undergo either somatic differentiation (Rabl, 1896; Von Berenberg-Gossler, '14) or degeneration (Beard, '02c; Jordan, '17). Others become cast off into the coelomic cavity (Beard, '02c) or into the lumen of the gut (Okkelberg, '21) and undergo degeneration. Still others have been observed to form cysts in various parts of the body. Some investigators believe that aberrant accumulations of these cells develop into dermoid cysts called embryomas. Beard ('02) seems to believe that:

"An embryoma, at whatever period it appear, is an instance of the development of an additional primary germ cell, which in all its hereditary character is the exact counterpart of that primary cell, by whose unfolding the individual harbouring the 'dermoid' arose"' (p. 672).

Okkelberg ('21) also found aberrant cysts of primordial germ cells in the fat body of the brook lamprey. However, he does not say what becomes of them, other than that they probably degenerate. Other investigators have recorded the presence of aberrant germ cells but attach no particular importance to them.

The present observations on the largemouth black bass support the theory of amoeboid migration for the primordial germ cells. Their movement is characterized by the formation of pseudopodial extensions which are usually blunt. This has also been demonstrated by Woodger ('25), Dantschakoff ('31a), and more recently by Witschi ('48). Situated as they are in early stages of development, there is little chance for the primordial germ cells to be shifted around by so-called normal processes of growth. The likelihood of their being incorporated within any blood vessel during its formation seems very slight. The shape of the primordial cells suggest that they are most active dưring the early phases of migration. After penetrating the splanchnic mesoderm their activity apparently is reduced and they assume a more or less rounded shape. The fact that these cells are able to assume a rounded form after an irregular one points towards independent move- 
ment. Some investigators seem to think that because the germ cells were seen by them as large rounded cells in the splanchnopleure they were incapable of independent movement. But as Allen ('06) has pointed out, the migration of the germ cells in the splanchnopleure might be so slight that irregularities in their shape would be imperceptible even to the most trained observer. It seems inconceivable that the germ cells in the bass should migrate in any other fashion than by independent movement. There is undoubtedly much wasted effort by these cells and Witschi ('48) probably is correct when he writes:

"Much of their migration represents compensating movements against the stream of growth that tends to carry them away from their goal" (p. 77).

At no time during their history are the germ cells far distant from the gonad primordia. No lost or wandering germ cells were observed in the bass. The path of migration of the germ cells apparently is determinate. From the very beginning of their migration they seem to be under the control of some directing force. Whether this force is chemotropic or mechanical is a matter of speculation. That it is mechanical is strengthened by the fact that the primordial cells make use of the potential coelomic space, and thus would be guided dorsad. Witschi ('48) favors the idea of a chemotropism as the directing force in the migration of the primordial germ cells in man. This concept, as he pointed out, is strengthened by the fact that leucocytes possess very definite chemotropic tendencies (Chambers and Grand, '36) and certain of their activities have been likened to those of primordial germ cells (Dantschakoff, '35).

No attempt was made in this study to ascertain the number of primordial germ cells reaching the gonad primordia. Allen ('11a) reported that only about half of the cells of Lepisosteus reach the gonads, whereas for Amia he concluded most all are successful. He was unable to account for the difference in the two forms. Others who have made statistical studies have found that the number varies to such an extent that no generalized statement can be made. 


\section{The periblast and the primordial germ cells}

During a short period of their history the primordial germ cells may be found in the periblast of the caudal extension of the yolksac. The periblast serves as a storage place for the cells from the time they become lodged there, early in development, until they begin their migration. Because of the type of development which occurs in the bass and certain other bony fishes, the periblast together with the yolk may be considered as being extra-embryonic. It is extra-embryonie, not in the sense that it lies outside of the embryo, but in the sense that it takes no material part in the formation of the embryo. Since this is the case, the germ cells, situated as they are in the periblast, may be considered as being extraembryonic also and are thus totally removed from any early chance inclusion in the soma.

Richards and Thompson ('21) found a close association between the periblast and the primordial germ cells in Fundulus. They found numerous instances where the germ cells "lay half-buried in the periblast." However, they were unable to attach any significance to this relationship. On the other hand, Reinhard ('24) described the primordial cells of Scardinius as originating from giant cells found in the periblast. Although there is reason to believe that he may have misinterpreted his material, he may have been more nearly correct than some believe. If in error, his mistake probably was due to the fact that he did not trace the giant cells back far enough and therefore made a natural but not too logical assumption that they originated from periblast nuclei. Hann ('27) observed these giant cells in Cottus and remarked that:

"Although the periblast nuclei are in close proximity to the giant cells, there is no evidence that the giant cells are derived from them" (p. 441).

Hann believed the giant cells to be of entodermal origin. Wolf ('31) first located the germ cells in Platypoecilus maculatus between the periblast and the ectoderm but doubted whether they had come from the periblast. Most investigators have managed to avoid the issue and make no statement regarding this relationship. 
The relationship that exists between the periblast and the primordial germ cells in Micropterus salmoides salmoides is comparable to that which exists between the primordial cells and the peripheral yolksac entoderm of other vertebrate forms. This concept has as its basis the assumption that the periblast in Micropterus is homologous with the yolksac entoderm of higher forms.

\section{Multiplication of the primordial germ cells}

In this study the question arose as to whether the primordial cells divide prior to reaching the gonad primordia. If they do not, what may account for their apparent increase from one stage to the next? Most investigators of germ cells in fishes find that they do not divide during migration (Figenmann, 1891; Beard, '00-'02 ; Woods, '02; Bohi, '04; Allen, '11a; Dodds, '10; Okkelberg, '21; Richards and Thompson, '21; Hann, '27; Dildine, '36; Moore, '37). On the contrary, other workers have reported that there is no apparent cessation of mitoses during the migration period, and some have described primordial germ cells in mitosis (Sink, '12 and others). It is generally agreed that cells do enlarge prior to division and that their cytoplasm has a tendency to take a lighter stain. Since both of these characteristics, large size and light-staining cytoplasm, have been used as criteria for the identification of primordial germ cells, there are some (Simkins, '23; Hargitt, '25) who believe that the large rounded cells identifiable as primordial germ cells are nothing but somatic cells preparing to divide. Certain large cells were observed in the present study. When followed through a complete division, however, the daughter cells were found to be somatic cells and not primordial germ cells. Measurements were made of these large cells, and it was found that even when most enlarged, they did not compare in size with primordial germ cells. Therefore, it is concluded that these enlarged cells are not primordial germ cells in mitosis.

The fact that the primordial germ cells apparently do increase in number from one stage to the next may be attributed 
to a sequence of events such as Dodds ('10) observed in Lophius wherein the germ cells became more conspicuous as differentiation of the soma increased. A similar condition was observed by Moore ('37) in the rainbow trout. His own statement (p. 107) concerning it is :

"In the 11-day embryo there are many more germ cells than in previous ages. Since no mitotic germ cells occur and since there is no evidence of differentiation of germ cells from somatic cells, it is possible that these cells are of blastodermic origin just taking on the distinctive characteristies of primordial germ cells."

\section{Number, size and distribution of the primordial germ cells}

According to Beard's ('02b) hypothesis the number of primordial germ cells occurring in any individual of a particular species is constant. This number, according to him, could be expressed by the formula $2^{\mathrm{n}-1}$. For Petromyzon, Beard ('02b) found the number of primordial germ cells to be $32^{-1}$. Most investigators have found that their results regarding the number of primordial germ cells could not be reconciled with Beard's formula. Eigenmann (1896), not yet aware of Beard's hypothesis, found that in Cymatogaster there was a striking variation in the number of primordial cells in different larvae and attributed these differences to individual variation. Allen ('07a), in his statistical study of the sex cells of Chrysemys marginata, reached similar conclusions and says:

"His [Beard's] conception of a specific number of sex cells expressed by the formula $2^{\mathrm{n}-1}$ during these early stages certainly is not borne out by the facts observed in Chrysemys, in which the number of sex cells ranges all the way from 302-1744" (p. 395).

In a later paper Allen ('11a) found that the number of primordial germ cells of Amia and Lepisosteus varied considerably and followed no specific formula.

Dodds ('10) also found that in Lophius the number of primordial cells varied from one individual to the next and definitely did not follow Beard's "Numerical Law of Germ 
Cells." Bachmann ('14) found that in Ameiurus nebulosus the number of primordial cells ranged from 12 to 34 , with an average of about 23. For Fundulus heteroclitus Richards and Thompson ('21) found 67 to be the average number of primordial cells. In Cottus bairdii (Girard) this variation was reported to range from 1 to 80 (Hann, '27). In Platypoecilus maculatus a variation of from 40 to 543 was reported (Wolf, '31). Although Goodrich et al. ('34) found the number of primordial germ cells in Lebistes to range from 37 to 66, Dildine ('36) for the same species found the

TABLE 5

The size of primordial germ cells in several vertebrates

\begin{tabular}{llll}
\hline INVESTigator & yEar & \multicolumn{1}{c}{ ANimaL } & size IN MiCRONS \\
\hline Eigenmann & 1891 & Micrometrus & 13 to 18 \\
Allen & $1911 \mathrm{a}$ & Lepidosteus & 10.27 to 14.95 \\
& $1911 \mathrm{a}$ & Amia & 11.59 to 21.88 \\
Swift & 1914 & Gallus & 14 to 22 \\
& & & average 16 \\
Bachmann & 1914 & Amieurus & 14 to 18 \\
Jordan & 1917 & Caretta & 13 to 20 \\
Essenberg & 1923 & Xiphophorus & 11.8 \\
Wolf & 1931 & Platypoecilus & 8.5 to 11.5 \\
Cheng & $1932 a$ & Rana & 16 to 24 \\
Risley & 1933 & Sternotherus & Average 17 \\
Goodrich et al. & 1934 & Lebistes & 10 to 14 \\
Dildine & 1936 & Lebistes & 13 to 19 \\
\hline
\end{tabular}

range to be from 17 to 35 . For the rainbow trout, Salmo irideus (Gibbons), Moore ('37) reported the number of primordial cells to be 84 .

The number of primordial cells in Micropterus salmoides salmoides varied from individual to individual. This variation (20 to 105) is so extreme that there is little chance that Beard's law would find any application here. There is less variation among individuals of the same egg masses than among those of different egg masses. Apparently this is a common occurrence and most likely is due to congenital factors (Hann, '27, and others). No overall average number of 
primordial germ cells was determined for Micropterus; however, if a careful statistical study were made, it probably would be about 60 .

Apparently the primordial germ cells of vertebrates vary less in size than they do in number. All those so far described would be classified as large cells (table 5).

The size of the primordial germ cells of Micropterus salmoides salmoides agrees quite well with those recorded for other vertebrates (tables 2 and 5 ). The variations in their size could be accounted for by change in shape during migration. Their magnitude may be attributed to a retention of the blastomeric qualities they possessed when first segregated. Thus, by comparing their size with that of early blastomeres it might be possible to determine the stage when they are first set aside in the blastoderm. Eigenmann (1891) also expresses such a view in the following statement:

"On comparing this size with segmenting eggs it is found that it agrees in size with some of the cells of an egg undergoing the 9th segmentation and in all probability it is a cell remaining unchanged from that stage" (pp. 484-485).

Maschkowziff ('34) finds that in both Salmo trutta and Acipenser stellatus the primordial germ cells are dimorphic as to size. This condition is, according to him, brought about through differences in the amount of yolk contained in them. $\mathrm{He}$ believes that this difference in yolk content is indicative of the sex potentiality of the cells. He says (pp. 65-66):

"Die primären Geschlectszellen sind von sweierlie Typus: kleine und grosse; ihr Unterschied wird dureh die verschiedene Quantität an Dotter im Protoplasma hervorgerufen ... Bei grosser Dotter-menge dominiert der weibliche Faktor, d.h. die grossen Ureier sind Geschlechtszellen vom weiblichen Typus. Bei einer kleinen Quantität Dotter dominiert der mannliche Faktor, d.h. die kleinen Ureier sind vom mannlichen Typus."

As his views are unique in the literature and cannot be reconciled with those of any other investigators, this topic warrants further investigation.

Several investigators have found that the primordial germ cells are distributed unequally to the gonad primordia. Others 
have found an almost equal distribution and still others have found no set pattern (table 6).

The germ cells of Micropterus salmoides salmoides are distributed asymmetrically to the gonad primordia with the greatest number going to the right. In some 6.5- to $7.5-\mathrm{mm}$ larvae, twice to three times as many germ cells are found

TABLE 6

The distribution of primordial germ cells to the gonad primordia in several vertebrates

\begin{tabular}{|c|c|c|c|}
\hline INVESTIGATOR & YEAR & ANIMAL & DISTRIBUTION \\
\hline Eigenmann & 1891 & Micrometrus & No uniform distribution \\
\hline \multirow[t]{2}{*}{ Allen } & $1911 \mathrm{a}$ & Lepidosteus & $\begin{array}{l}\text { More germ cells in the } \\
\text { left primordium }\end{array}$ \\
\hline & & Amia & $\begin{array}{l}\text { More germ cells in the } \\
\text { right primordium }\end{array}$ \\
\hline Swift & 1915 & Gallus & $\begin{array}{l}\text { Decided preference for } \\
\text { the left primordium }\end{array}$ \\
\hline Jordan & 1917 & Caretta & About equally distributed \\
\hline Hann & 1927 & Cottus & Unequal distribution \\
\hline Cheng & 1932 & Rana & $\begin{array}{l}\text { No marked variation in } \\
\text { distribution }\end{array}$ \\
\hline Risley & 1933 & Sternotherus & $\begin{array}{l}\text { More germ cells oceur in } \\
\text { the left primordium }\end{array}$ \\
\hline Blocker & 1933 & Passer & $\begin{array}{l}\text { More germ cells in the } \\
\text { left primordium }\end{array}$ \\
\hline Witsehi & 1935 & Passer & $\begin{array}{l}3 \text { to } 10 \text { times as many } \\
\text { germ cells in the left }\end{array}$ \\
\hline Dildine & 1936 & Lebistes & Unequal distribution \\
\hline \multicolumn{4}{|l|}{ Stanley and } \\
\hline Witsehi & 1940 & Hawk & Unequal distribution \\
\hline
\end{tabular}

in the right primordium as in the left. This asymmetrical distribution may be attributed to a reduction in the potential if not actual migration area, resulting from the formation of the subintestinal vein.

\section{Sex differentiation}

Although in Micropterus salmoides salmoides there is a long period of gonadal development prior to sex differentia- 
tion, it is a period of indifference and not of juvenile hermaphroditism, such as has been reported by Müller (1875), Cunningham (1887), Beard (1893), Dean (1897), Lubosch ('03), Okkelberg ('21), Essenberg ('23), Mršić ('30), Goodrich et al. ('34), Dildine ('36), and others. The gonads do not exhibit bisexual tendencies nor do they undergo regression (Essenberg, '23). The gonads are structurally different from sex differentiation on and most likely this difference is due to a difference in the chromosomal constituency of the germ cells and of the somatic cells comprising them.

Preliminary studies on sex ratios support the theory of a chromosomal mechanism for sex determination. However this is not substantiated by either experimental or detailed observations of the germ cells during division.

\section{SUMMARY}

1. Observations support an early segregation of the germ cells. They are first recognizable in an excrescence at the dorsal lip of the blastopore.

2. Primordial germ cells make their way into the periblast ventral to the dorsal lip and are shifted caudad in the caudal extension of the yolksac.

3. Primordial germ cells migrate by amoeboid movement. The path of migration is from the yolksac extension through the splanchnic mesoderm into the potential coelom, thence dorsal to the crest of the gut and through the mesentery and laterally adjacent mesoderm to the gonad primordia.

4. Germ cells do not divide prior to reaching the region of the gonad. Their apparent increase in number from one stage to the next is most likely due to their becoming more conspicuous as somatic differentiation progresses. The number of germ cells is more constant among individuals from the same egg mass than among those from different egg masses.

5. Primordial germ cells possess no special feature by which they can be identified. They are large cells with the general features which usually characterize primordial germ 
cells. Their magnitude is due to a retention of their original size as early blastomeres.

6. The germ cells are asymmetrically distributed to the gonad primordia, the right receiving the larger number. This is a result of a reduction in the potential migration area on the left side associated with the formation of the subintestinal vein.

7. No germ cells become located in the gonadal epithelium of the bass. They lie against, but not in the epithelium; hence, it is not germinal in nature. There is no transformation of stromal or epithelial cells into germ cells. The definitive sex cells are derived from the primordial germ cells only.

8. The presence of germ cells is apparently necessary for the formation of the gonad. After its formation, and prior to sex differentiation, the gonad passes through a long period of sexual indifference. During this time it increases in size through an increase in the amount of both germinal and stromal elements.

9. The indifferent gonad shows an anteroposterior gradation of development, the posterior portion developing earlier.

10. The gonads remain paired anteriorly but they fuse posteriorly. Each contains a gonocoel made patent by a separation of two layers of epithelium delaminated early in development. The gonocoels unite into a common cavity in the fused portions of the gonads and continue as a median oviduct or vas deferens.

11. Sex may be recognized at the $3-\mathrm{cm}$ stage through the growth of gonia in females.

12. The early ovary and testis differ not only in structure but also in the number of germinal cells. The early ovary possesses a thick connective tissue tunic, which the testis lacks; the ovocoel is lined with low, irregular cuboidal cells; and the mesovarium is broad while the mesorchium is thin and delicate.

13. Sex may be recognized in gross dissection in the $4.0-\mathrm{cm}$ stage. The ovaries are distended, while the testes are thin 
strands. Both the ovaries and the testes are suspended along the ventral surface of the swimbladder.

14. The later ovary possesses ovigerous lamellae which project into the ovocoel. Both the oocytes and the ova are in various stages of growth and yolk formation. The nucleus of the growing oocyte loses its reticular structure and its chromatin collects into numerous rounded bodies peripherally arranged along the nuclear membrane.

15. The later testis is tubular. The spermatogonia lie in the walls of the tubules but do not form a part of their epithelium. Tubules are formed through outgrowths of the testocoel. The testocoel corresponds to a primary collecting duct and its branches to secondary and tertiary ducts.

\section{LITERATURE CITED}

Abramowicz, Helene 1913 Die Entwicklung der Gonadenanlage und Entstehung der Gonocyten bei Triton taeniatus (Schneid). Morph. Jahrb., 47 : 593-644.

ALLeN, B. M. 1904 The embryonic development of the ovary and testis of the mammals. Am. J. Anat., $3:$ 89-154.

1906 The origin of the sex cells of Chrysemys. Anat. Anz., 99 : 217-236.

1907a A statistical study of the sex cells of Chrysemys marginata. Anat. Anz., 30: 391-399.

1907b An important period of the sex cells in Rana pipiens. Anat. Anz., 31: 339-347.

1911a The origin of the sex cells of Amia and Lepidosteus. J. Morph., 22: 1-36.

1911b The origin of the sex cells in Necturus. Science N. Y., 33 : 268-269.

Bachmann, Freda M. 1914 The migration of the germ cells in Amiurus nebulosus. Biol. Bull., 26 : 351-366.

Batifour, F. M. 1877 The development of Elasmobranch fishes. J. Anat. Phys., 11: 128.

Beard, J. 1893 Hermaphroditism of lampreys. J. Roy. Micr. Soc. London, 1893 (2) : 156 .

1900 The morphological continuity of the germ cells in Raja batis. Anat. Anz., 18 : 465-485.

1902a The germ cells of Pristiurus. Anat. Anz., 21: 50-61.

$1902 \mathrm{~b}$ The numerical law of the germ cells. Anat. Anz., 21: 189-200.

1902e The germ eells. Part I. Raja batis. Zool. Jahrb., 16: 615-702. 
BECCARI, N. 1922 Studî sulla prima origine delle cellule genitali nei Vertebrati. II. Ricerche nella Salamandrina perspicillata. Arch. Ital. Anat., supp., 18: $29-95$.

1924 Studî sulla prima origine delle cellule genitali nei vertebrati. III. Ricerehe nel Bufo viridis. Arch. Ital. Anat. Embry., 21: 332-374.

Bennington, N. L. 1936 Germ cell origin and spermatogenesis in the Siamese fighting fish, Betta splendens. J. Morph., $60: 103-126$.

Berenberg-Gossler, H. voN 1912 Die Urgesehlechtszellen des Hühnerembryos am 3 und 4 Bebrütungstage mit besonderer Berücksichtigung der Kernund Plasmastrukturen. Areh. f. mikr. Anat., 81: 24-72.

1914 Ueber Herkumft und Wesen der sogenannten primären Urgeschlechtszellen der Amnioten. Anat. Anz., 47: 241-264.

Berg, Leo S. 1940 Classification of fishes both recent and fossil. Travaux l'Inst. Zool. Aead. Sei. URSS, 5: 87-517. (Lithoprinted 1947, Edwards Bros., Ann Arbor.)

BLOCKER, HUberT W. 1933 Embryonic history of the germ cells in Passer domesticus (L.). Acta Zool., 14: 111-152.

Bơr, U. 1904 Beiträge zur Entwicklungsgeschichte der Leibeshöle und der Genitalanlage bei Salmoniden. Morph. Jahrb., 32: 505-586.

Bookhout, Cazlyn G. 1937 The germ cell eycle in the guinea pig. I. The embryonie development of the testis. II. The postnatal development of the testis. Zeit. f. Zellforsch. mikr. Anat., 25: 728-763.

Bours, M. 1900 Ébauche génitale primordiale chez Rana temporaria. Bibliog. Anat., 8 : 103-108.

1901 Histogenèse de la gland génitale femelle chez Rana tamporaria (L). Arch. de Biol., 17 : 201-381.

Bounoure, L. 1924a Dérivés endodermiques dorsaux et première ébauche génitale chez les betraciens anoures. Compt. rend. Aead. Sei. Paris, 178: 339-341.

1924b Origine des gonocytes primaries chez les Urodeles et signification des ces éléments chez les amphibiens en général. Compt. rend. Acad. Sei. Paris, 179: 1082-1084.

1925 L'origine des gonocytes et I'évolution de la première ébauche génitale chez les batraciens. Ann. Sci. Nat. Zool., 8: 201-278.

1934 Recherches sur la lignée germinale chez la genouille rousse aux premier stades du développement. Ann. Sei. Nat. Zool., 17: 67-248.

BRAMrele, F. W. R. 1927 The development and morphology of the gonads of the mouse. Part I. The morphogenesis of the indifferent gonad and of the ovary. Proc. Roy. Soc. B, 101: 391-409.

Burger, J. Wendell 1937 The continuity of the germ cells in the urodele Plethodon cinereus (Green). J. Morph., 60: 489-514.

Burns, R. K. 1925 The sex of parabiotic twins in Amphibia. J. Exp. Zool., 4O: $31-90$.

Butcher, E. O. 1927 The origin of the definitive ova in the white rat (Mus norvegicus albinus). Anat. Rec., 37: 13-30.

1929 The origin of the germ cells in the lake lamprey Petromyzon marinus unicolor. Biol. Bull., 56: 87-99. 
Chambers, R., ANd C. G. Grand 1936 The chemotactic reaction of leucocytes to foreign substances in tissue culture. J. Cell. and Comp. Physiol., 8 : 1-19.

Champy, C. 1913 Recherches sur la spermatogénèse des batrachiens et les éléments accessoires du testicule. Arch. zool. exp. et gen., 52: 13-304.

CheN, H. K. 1930 Origin of germ cells in Necturus. Shanghai J. Sei., 3: 44-75. Cheng, Tso-Hsin 1932a The germ cell history of Rana cantabrigensis Baird. I. Germ cell origin and gonad formation. Zeit. f. Zellforsch. mikr. Anat., 16 : 497-541.

1932b The germ cell history of Rana cantabrigensis Baird. IT. Sex differentiation and development. Zeit. f. Zellforsch. mikr. Anat, 16: $542-596$.

Christensen, K. 1930 Sex differentiation and development of the oviduct in Rana pipiens. Am. J. Anat., 45 : 159-187.

da Costa, Cetestino A. 1932 Les gonocytes primares chez les gonocytes chez les mammiferes (guinea pig). Compt. rend. Assoc. Anat., 27 : 198-212.

CoWPerthwarte, M. H. 1925 Observations on pre- and postpubertal oogenesis in the white rat, Mus norvegicus albinus. Am. J. Anat., 36: 69-89.

CUNNINGHAM, J. T. 1887 On the structure and development of the reprodnctive elements in Myxine glutinosa. Quart. J. Micr. Sci., 27: 49-76.

DantschakoFF, Wera 1931a Keimzelle und Gonade. I. A. Von der entodermalen Wanderzelle bis zur Urkeimzelle in der Gronade. Zeit. Zellforsch. mikr. Anat., 13 : 448-510.

1931b Keimzelle und Gonade. Die entodermale Wanderzelle als Stammzelle in der Keimbahn. Experimentelle Beweise. Zeit. Zellforseh. mikr. Anat., 14: 376-384.

1935 Sur les facteurs determinant l'emplacement des gonades chez le poulet. Comp. rend. Acad. Sci. (Paris), 200: 1495-1497.

Dantschakoff, Wera, Wera Dantschakoff, JR. ANd Lydia Bereskina 1931 I. Al Identität der Urkeimzellen und der entodermalen Wanderzellen. Experimentelle Beweise. Zeit. Zellforsch. mikr. Anat., 14: 333-375.

DEAN, B. 1897 On a plan of development of a myxinoid. Seience, $5: 435$.

Dildine, Glenn C. 1936 Studies on teleostean reproduction. I. Embryonic hermaphroditism in Lebistes reticulatus. J. Morph., 60: 261-277.

DoDds, G. S. 1910 (On) The segregation of the germ cells of the teleost, Lophius. J. Morph., 21 : 563-612.

Dustin, A. P. 1907 Recherches sur 1'origine des gonocytes chez les amphibiens. Arch. de Biol., 23 : 411-522.

1910 L'origine et l'évolution des gonocytes chez les Reptiles (Chrysemys marginata). Arch. de Biol., 25: 495-544.

EIGENMANN, C. H. 1891 On the precocious segregation of the sex eells in Micrometrus aggregatus Gibbons. J. Morph., 5: 481-492.

1896 Sex differentiation in the viviparous teleost Cymatogaster. Arch. Ent. Mech., 4: 125-179.

Essenberg, J. M. 1923 Sex differentiation in the viviparous teleost Xiphophorus helleri Heckel. Biol. Bull., 45: 46-97. 
Everett, N. B. 1942 The origin of ova in the adult opossum. Anat. Rec., 82: 77-91.

1943 Observational and experimental evidences relating to the origin and differentiation of the definitive germ cells in mice. J. Exp. Zool., 92: 49-91.

1945 The present status of the germ cell problem in vertebrates. Biol. Rev., 20: 45-55.

Feberow, W. 1907 Über die Wanderung der Genitalzellen bei Salmo fario. Anat. Anz., 31: 219-223.

Frrket, J. 1914 Recherches sur l'organogénèse des glandes sexuelles chez les oiseaux. Arch. de Biol., 29: 201-351.

1920a Recherches sur l'organogénèse des glandes sexuelles chez les oiseaux. Arch. de Biol., 30: 393-516.

$1920 \mathrm{~b}$ On the origin of germ cells in higher vertebrates. Anat. Rec., $18: 309-316$.

Fischer, Isle 1935 Zur Keimbahn frage bei den Urodelen Amphibien. Jahr. Morph. Mikr. Anat., Abt. II, Zeit. Mikr. Anat. Forseh., 37 : $219-244$.

Foley, James O. 1927 Observations on germ-cell origin in the adult male teleost, Umbra limi. Anat. Rec., 35: 379-399.

GATENBy, J. B. 1916 The transition of peritoneal epithelial cells into germ cells in some amphibian anura, especially Rana temporaria. Quart. J. Micr. Sci., $61: 275-300$.

GoETTE, A. 1890 Entwicklungsgeschichte des Flussneunauges (Petromyzon fuviatilis). Abh. zur Ent. der Thiere. Heft 5, Teil 1. 95 p. Hamburg u. Leipzig.

Goldsmith, J. B. 1928 The history of the germ cells in the domestie fowl. J. Morph. Physiol., $46: 275-316$.

1935 The primordial germ cells of the chick. I. The effect on the gonad of complete and partial removal of the "germinal crescent" and of removal of other parts of the blastodisc. J. Morph., 58:537-553.

Goodrich, H. B., J. E. Dee, C. M. Flynn and Rowena M. Mfrcer 1934 Germ cells and sex differentiation in Lebistes reticulatus. Biol. Bull., 67 : $83-96$.

HaLl, R. W. 1904 The development of the mesonephros and the Mullerian ducts in Amphibia. Bull. Mus. Comp. Zool., 45 : 31-126.

Hamlett, G. W. D. 1935 Primordial germ cells in a $415 \mathrm{~mm}$ human embryo. Anat. Rec., 61: 273-279.

HaNN, H. W. 1927 The history of the germ cells of Cottus bairdii Girard. J. Morph. Physiol., 43: 427-498.

HARGITT, G. T. 1924 Germ cell origin in the adult salamander, Diemyctylus viridescens. J. Morph. Physiol., 39: 53-112.

1925 The formation of the sex glands and germ cells of mammals.

I. The origin of the germ eells in the albino rat. J. Morph. Physiol., $40: 517-558$.

Heys, Florence 1931 The problem of the origin of germ cells. Quart. Rev. Biol., 6 : 1-45. 
Hoffman,, C. K. 1886 Zur Entwicklungsgeschichte der Urogenitalorgane bei den Anamnia. Zeit. f. Wiss. Zool., 44: 570-643.

1893 Étude sur le développement de l'appareil urogenital des oiseaux. Verhl. Akad. Wetensch. Amsterdam, Wiss. en. natuurkd. afd., II, $1 \mathrm{Nr} .4,54$.

Humphrex, R. R. 1925 The primordial germ cells of Hemidactylium and other Amphibia. J. Morph. Physiol., 41: 1-43.

James, Marian F. 1946 Histology of gonadal changes in the bluegill, Lepomis macrochirus Raf., and the largemouth bass, Huro salmoides (Lacépède). J. Morph., $79: 63-92$.

JARVIS, Max 1908 The segregation of the germ cells of Phrynosoma cornutum. Preliminary note. Biol. Bull., 15: 119-126.

JoRDAN, H. E. 1917 Embryonic history of the germ cells of the loggerhead turtle (Caretta caretta). Carnegie Inst. Wash., Publ. 251: 313-344.

KING, HeLen D. 1908 The oogenesis of Bufo lentiginosus. J. Morph., 19: 369436.

KINGERY, H. M. 1917 Oogenesis in the white mouse. J. Morph., 30: 261-316.

KINGSBURY, B. F. 1913 The morphogenesis of the mammalian ovary: Felis domestica. Am. J. Anat., 14: 345-379.

1938 The post-partum formation of egg cells in the eat. J. Morph., 63 : $397-419$.

KIRKhaM, W. B. 1916 The germ eell cycle in the mouse. Anat. Ree, 10: 217219.

Kuschakewitsch, S. 1910 Die Entwieklungsgeschichte der Keimdrüsen von Rana esculenta. Ein Beitrag zum Sexualitätsproblem. Fest. zum 60, Geburt. R. Hertwigs, 2: 61-224.

Lubosch, W. 1903 Ueber die Gesehlechtsdifferenzierung bei Ammocoetes. Anat. Anz., 23: 66-74.

MacLeod, J. 1881 Recherches sur la structure et la développement de l'appareil reproductive femelle des Teleosteens. Areh. de Biol., 2: 497-532.

Maschkowziff, AlEx 1934 Zur Phylogenie der Geschlechtsdrüsen und der Geschlechtsausführgänge bei den Vertebra auf Grund von Forschungen betreffend die Entwicklung des Mesonephros und der Geschlechtsorgane bei den Acipenseridae, Salmoniden und Amphibien. I. Die Entwicklung des Mesonephros und der Genitaldrüse bei den Acipenseridae und Salmonidae. Zool. Jahrb. Abt. Anat. u. Ont., 59: 1-68.

McCosh, Gladys K. 1930 The origin of the germ cells in Amblystoma maculatum. J. Morph., $50: 569-611$.

Moore, G. A. 1937 The germ cells of the trout (Salmo irideus Gibbons). Trans. Am. Mier. Soc., 56 : 105-112.

MRšć, W. 1930 Ueber das Auftreten intermediarer Stadium bei der Geschlechtsdifferenzierung der Forelle. Arch. Entwmech. Org., 123: 301-332.

Müller, JohanN W. A. A. 1875 Ueber das Urogenitalsystem des Amphioxus und der Cyclostomen. Jena Zeit. Naturw., 9: 94-129.

Nieuwkoop, P. D. 1946 Experimental investigations on the origin and determination of the germ cells and the development of the lateral plate and germ ridges in the Urodeles. Arch. Neerland. De Zool., 7: 1-205. 
Nussbaum, M. 1880 Zur Differenzierung der Geschlechter im Thierreich. Arch. f. mikr. Anat., 18: 1-121.

1901 Zur Entwickelung des Geschlechts beim Huhn. Vehr. Anat. Ges., Vers., 15 : 38-40.

OrReshkove, V. 1924 Accessory testicular lobes in Diemyctylus viridescens, their probable origin and significance. J. Morph. Physiol., 39: 1-46.

Odum, E. P. 1936 Notes on the history of the germ cells in the Toadfish, Opsanus tau. J. Elisha Mitchell Sci. Soc., 52: 235-246.

OkKelberg, P. O. 1921 The early history of the germ cells in the brook lamprey, Entosphenus wilderi (Gage), up to and including the period of sex differentiation. J. Morph., 35: 1-152.

PerLe, S. 1927 Origine de la première ebauche genitale chez Bufo vulgaris. Compt. rend. Acad. Sci. Paris, 184: 303-304.

Politzer, G. 1933 Die Keimbahn des Menschen. Zeit. Ges. Anat. abt. I. Zeit. Anat. u. Entwicklungsges., 100: 331-361.

RABL, C. 1896 Über die Entwicklung des Urogenital systems der Selachier. Morph. Jahrb., 24: 632-767.

Reagan, F. P. 1916 Some results and possibilities of early embryonic castration. Anat. Rec., 11: 251-267.

Reinhard, Leonid 1924 Die Entwicklung des Parablasts und seine Bedeutung bei Telostiern nebst der Frage über die Entstehung der Urgeschlechtszellen. Areh. f. Mikr. Anat. u. Ent., 103: 339-356.

Richards, A., AND J. T. Thompson 1921 The migration of the primary sex-eells of Fundulus heteroclitus. Biol. Bull., 40: 325-348.

Richards, A., H. R. Hulpieu and J. B. Goldsmith 1926 A restudy of the germcell history in the fowl. Anat. Rec., $34: 158$.

Risley, PaUl L. 1933 Contributions on the development of the reproductive system in Sternotherus odoratus (Latreille). I. The embryonic origin and migration of the primordial germ cells. Zeit. f. Zellforsch. u. mikr. Anat., 18: 459-492.

1934 The activity of the coelomic (germinal) epithelium of the male musk turtle Sternotherus odoratus (Latreille). J. Morph., 56: 59-99.

RUCKERT, J. 1888 Über die Entstehung der Excretionsorgane bei Selachiern. Arch. Anat. u. Phys., Anat. Abt., 2: 205-278.

Rubaschin, W. 1907 Über das erste Auftreten und Migration der Keimzellen bei Vogelembryonen. Anat. Hefte, $35: 241-261$.

1908 Zur Frage von der Entstehung der Keimzellen bei Säugetierembryonen. Anat. Anz., 32: 222-224.

1909 Über die Urgeschlechtszellen bei Säugetieren. Anat. Hefte, $39: 603-652$.

1910 Chondriosomen und Differenzierungsprocesse bei Säugetierembryonen. Anat. Hefte, $41: 399-431$.

1912 Zur Lehre von der Keimbahn bei Säugetieren. Über die Entwicklung der Keimdrüsen. Anat. Hefte, $46: 343-411$.

SaInanont, G. 1906 Recherches relatives a l'organogénèse du testicle et 1'ovaire chez le chat. Arch. de Biol., 22: 71-163. 
Schapitz, Reinhold 1912 Die Urgeschlechtszellen ron Amblystoma. Arch. f. mikr. Anat., Abt. II, 79: 41-78.

Semon, R. 1891 Studien über den Bauplan des Urogenitalsystems der Wirbeltiere. Dargelegt an der Entwicklung dieses Organsystems bei Ichthy. ophis glutinosus. Jena Zeit. Med. Naturwiss., 26: 89-203.

Semper, C. G. 1875 Das Urinogenitalsystem der Plagiostomen und seine Bedeutung für der übrigen Wirbeltiere. Arbt. Zool. Inst. Würzburg, 1875, 2: 195-509.

SeshachaR, B. R. 1937 Germ-cell origin in the adult Caecilian Ichthyophis glutinousus (Linn.). Zeit. Zellforseh. u. Mikr. Anat., 26: 293-304.

Simkins, C. S. 1923 On the origin and migration of the so-called primordial germ cells in the mouse and the rat. Acta Zool., $4: 241-284$.

1925 Origin of the germ cells in Trionyx. Am. J. Anat., 36:185-214.

Sink, E. W. 1912 The origin of the germ cells in the toadfish (Opsanus tau). Mich. Acad. Sei. Rep., 14: 212-215.

SPehl, G., AND J. Pouts 1912 Les premiers stades du développement des glandes génitales chez 1'axolotl. Arch. de Biol., 27 : 63-90.

Stanley, Allan J., AND E. Witschi 1940 Germ cell migration in relation to asymmetry in the sex glands of hawks. Anat. Rec., 76:329-342.

Swift, Charles H. 1914 Origin and early history of the primordial germ-cells in the chick. Am. J. Anat., 15: 483-516.

1916 Origin of sex-cords and spermatogonia in male chicks. Am. J. Anat., $20: 373-410$.

SwIngle, W. W. 1921 The germ cells of anurans. I. The male sexual cycle of Rana catesbeiana (Larvae). J. Exp. Zool., 32: 235-237.

1926 The germ cells of anurans. II. An embryological study of sex differentiation in Rana catesbeiana. J. Morph., 41: 441-546.

Trabucco, Armando 1938 Origin y evolution de la cellula germinal primaria. Semana Med., 48: 261-271.

Tschaschkin, S. 1910 Ueber die Chondriosomen der Urgeschlechtszellen bei Vogelembryonen. Anat. Anz., 37: 597-607, 621-631.

VAnNEMAN, A. S. 1917 The early history of the germ cells in the armadillo, Tatusia novemcincta. Am. J. Anat., 22: 341-364.

VAN OoRDT, G. J. 1924 The relation between the development of the secondary sex characters and the strueture of the testis in the teleost Xiphophorus helleri. Brit. J. Exp. Biol., 3: 43-59.

WALDEYer, W. 1870 Eierstock und Ei. Leipzig.

Wheeler, W. M. 1899 The development of the urinogenital organs of the lamprey. Zool. Jahrb. Abt. f. Anat., 13: 1-88.

WiJhe, J. W. vaN 1889 Über die Mesodermsegments des Rumpfes und die Entwicklung des Excretionssystems bei Selachiern. Arch. f. mikr. Anat., $3.3: 461-516$.

Winiwarter, H. von, AND G. SAINMONT 1909 Nouvelles recherches sur 1'orogeneses et 1 'organogénèse de l'oraire des Mammiferes (chat). Arch. de Biol., 24: 1-14:, 165-276, 373-431, 697-650. 
Wiтschi, EmIL 1914 Experimentelle Untersuchungen über die Entwicklungsgeschichte der Keimdrüsen von Rana temporaria. Arch. f. mikr. Anat,, 85: and $86: 9-113$.

1929 Studies on sex differentiation and sex determination in amphibians. I. Development and sexual differentiation of the gonads of Rana sylvatica. J. Exp. Zool., 52: 235-266.

1935 Die Amphisexualität der embryonalen Keimdrüse des Haussperlings, Passer domesticus L. Biol. Centralblatt, 55 : 168-174.

1948 Migration of the germ cells of human embryos from the yolk sac to the primitive gonadal folds. Carnegie Inst. Wash. Publ., 575, Contributions to Embryology, 32: 67-80.

WoLF, L. E. 1931 The history of the germ cells in the teleost, Platypoecilus maculatus. J. Morph., 52: 115-154.

WOODGER, J. H. 1925 Observations on the origin of the germ cells of the fowl, Gallus domesticus, studied by means of their Golgi bodies. Quart. J Mier. Sci., 69 : 445-462.

Woods, F. A. 1902 Origin and migration of the germ eells in Acanthias. Am. J. Anat., 1: 307-320.

\section{PLATE 1}

\section{EXPLANATION OF FIgURES}

5 An almost midsagittal section of the excrescence of potential germ cells at the dorsal lip of the blastopore ( $d \mathrm{ll} b \mathrm{p}$ ). Observe the presence of two and possibly three potential primordial germ cells (pge) lying between the dorsal lip ( $d \mathrm{ll} b$ ) and the periblast. Approximately $\times 540$.

6 A parasagittal section of the late gastrula showing the formation of the excrescence (exe) of potential primordial germ cells. Note the potential germ cell (pge) just within the dorsal lip. Approximately $\times 540$.

7 A section through the hindgut region of a 32 -hour embryo. In this section three germ cells (ge 1,2 and 3) are seen lying in the periblast. Approximately $\times 250$.

8 A section through a 41-hour embryo at the level of junction of the yolksac extension with the yolksac. A germ cell (ge) is seen lying in the mesoderm just to the left of the gut. Approximately $\times 250$.

9 A portion of the periblast ventral to Küpffer's vesicle in a 22 -hour embryo. A germ cell (ge) may be seen lying in the periblast ventral to the cells of the vesicle $(\mathrm{kv})$. Note that the outline of the germ cell is very distinct. Approximately $\times 1500$.

10 An enlargement of the germ cells and periblast shown in figure 7 . Note the definite cellular outline of the germ cell (ge) and the formation of what appears to be pseudopodial extensions of the cytoplasm. Approximately $\times 1500$. 

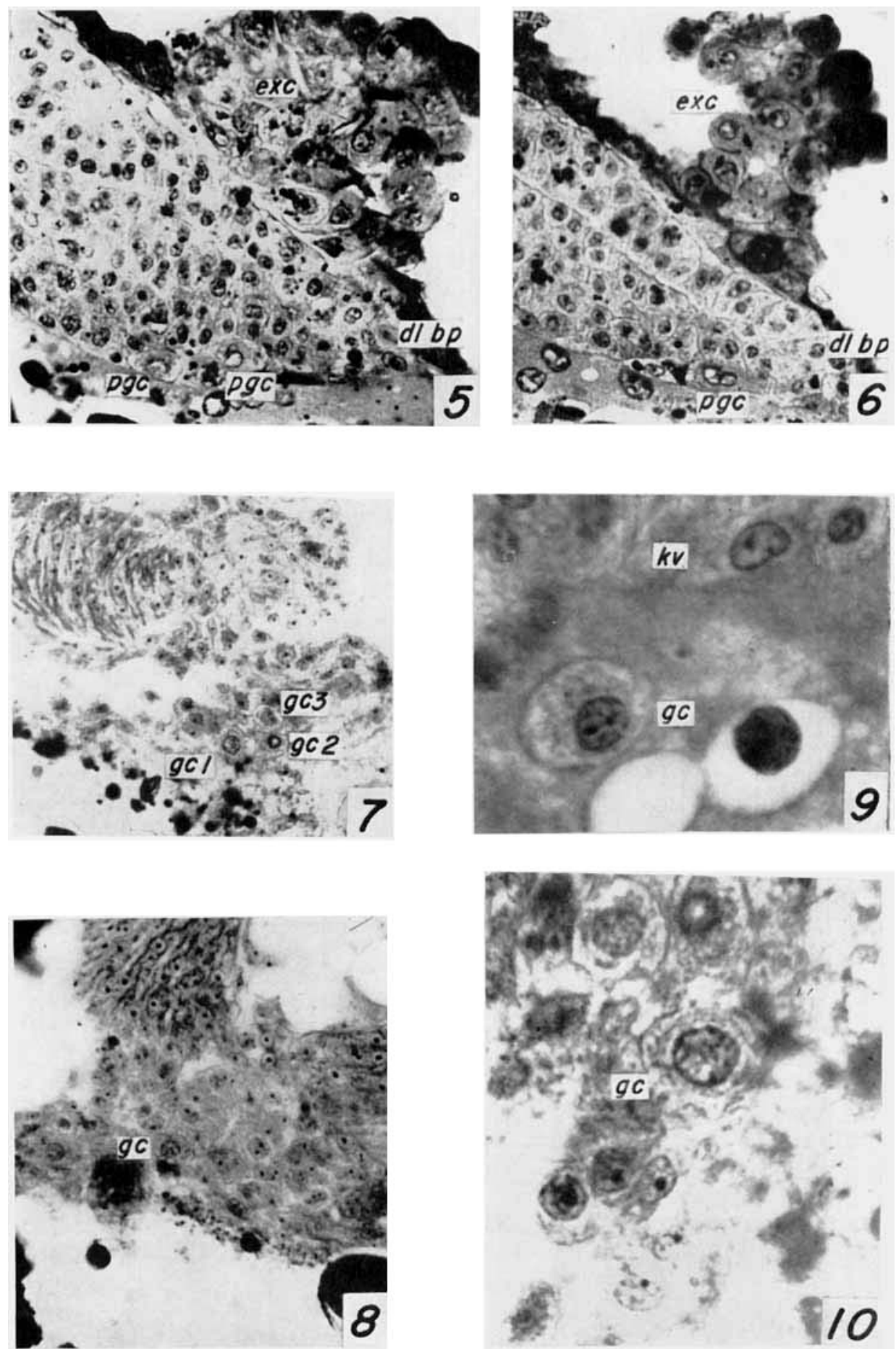


\section{PLATE 2}

\section{EXPLANAI'ION OF FIGURES}

11 A transverse section through a 37-hour embryo at the level of junction of the yolksac extension. Two germ cells may be seen. One lies in the periblast (ge 1) and the other in the mesoderm just ventral to the gut (ge 2). These cells are apparently in the process of migrating out of the yolksae extension. See text for additional description. Approximately $\times 720$.

12 A section through the posterior trunk region and the yolksac extension of a 44-hour embryo. A primordial germ cell is seen ventral to the left pronephrie duct (pnd). The large space within which the germ cell is lying is the yolksac extension (yse). This space was once filled with periblastic yolk, which was withdrawn prior to fixation. Observe the formation of the subintestinal vein (siv) ventrally. Approximately $\times 600$.

13 A higher magnification of the pronephric duct region of figure 12. Observe the granular cytoplasm and diffuse arrangement of the chromatin in the nucleus of the primordial germ cell (ge). Close observation will disclose that the germ cell possesses a blunt pseudopodium directed dorsally. Approximately $\times 1760$.

14 A transverse section through the posterior trunk region of a 44-hour embryo. Two germ cells (ge 1 and ge 2) may be seen lying in the mesoderm to the right and left of the gut. Approximately $\times 600$.

15 A section posterior to that shown in figure 14. A germ cell possessing a distinct attractionsphere is seen lying in the yolksac extension. Approximately $X$ 600.

16 A section taken posterior to that shown in figure 15 and almost to the posterior limit of the yolksae shows a germ cell (ge) lying in the ventral mesentery (vm). Note the similarity of its nucleus with that of previously demonstrated germ cells. Observe how definite its outline is as contrasted with those of somatic cells. Approximately $\times 600$. 
PERRY MAX JOHNSTON
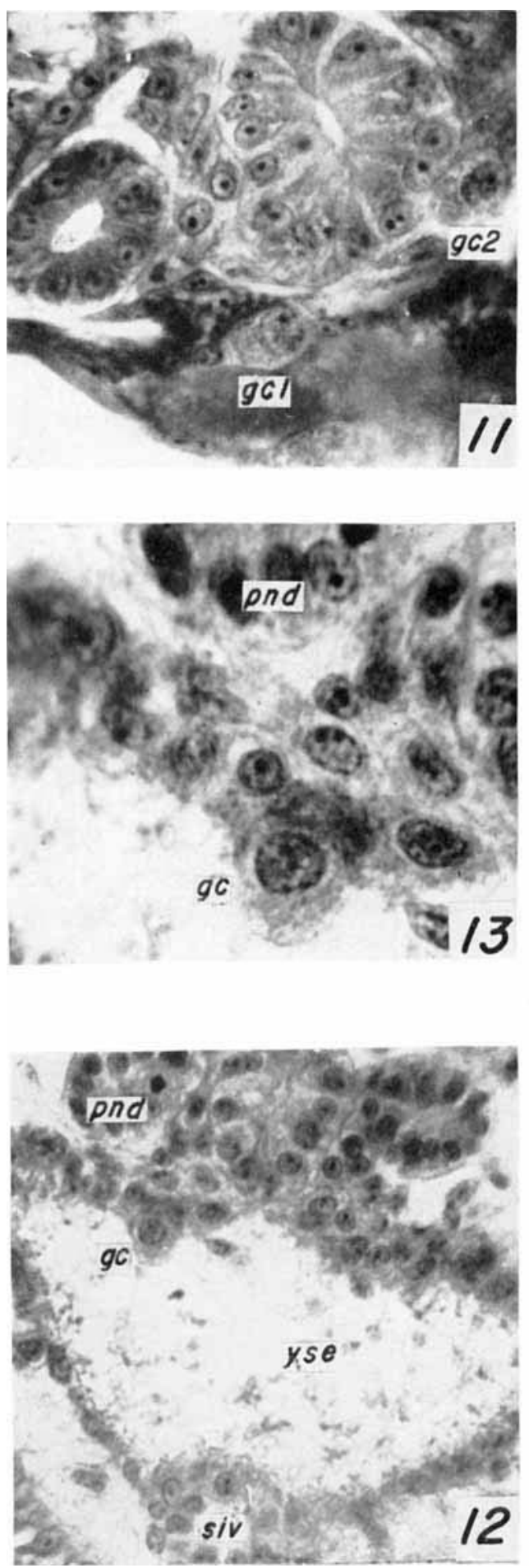
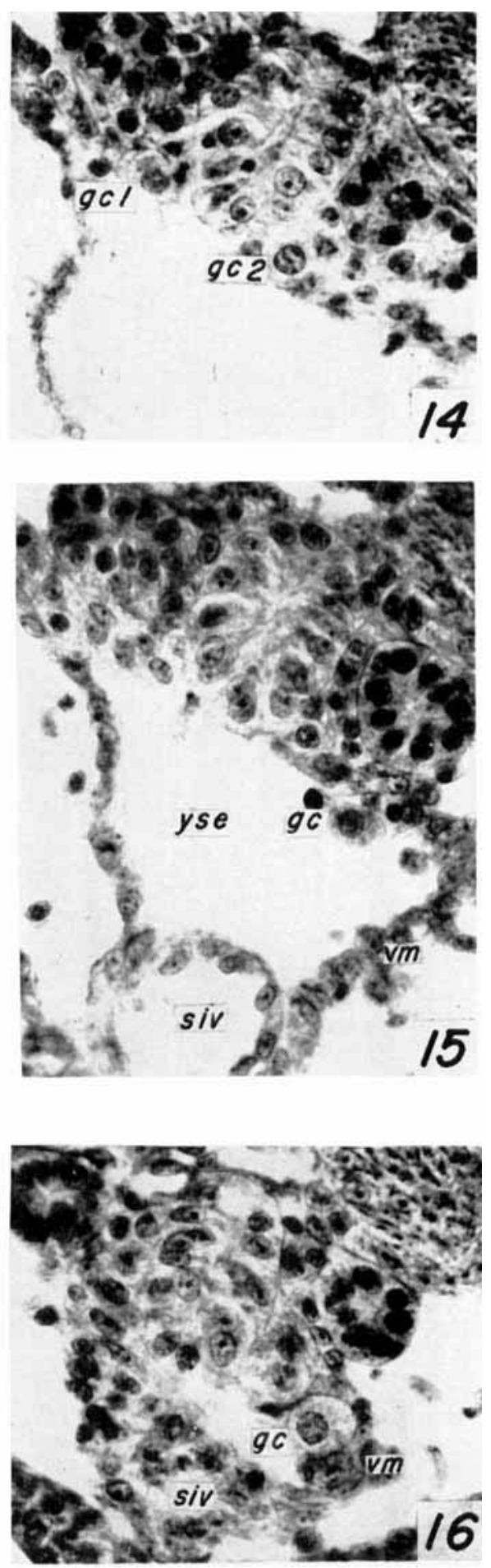


\section{PLATE 3}

\section{EXPLANATION OF FIGURES}

17 A transverse seetion through the posterior trunk region of a $3.5-\mathrm{mm}$ larva. This section shows the relative positions of the subintestinal vein (siv), the yolksac extension (yse), and the gut. The coelom is not yet formed and the gut is seen bounded by large lymph spaces (ls). Note the relative size of the yolksac extension and compare with figure 12 . Approximately $\times 340$.

18 A cross section through the yolksac extension of a 45 -hour embryo. During preparation the mesentery was slightly torn. A primordial germ cell (ge) may be seen lying next to a primitive blood cell. The periblast yolk, with several periblastic nuclei (pbn), partly fills the extension. Approximately $\times 480$.

19 An enlargement of the region adjacent to the germ cell of figure 18. Observe that the eytoplasm of the germ cell is arranged into a "cap" around the nucleus. Note the attractionsphere to the right of the nucleus in the germ cell. Approximately $\times 1300$.

20 A eross section through the yolksae extension of a 45-hour embryo showing two germ cells (ge 1 and ge 2) lying in the extension ventral to the gut. Germ cell 1 possesses an attractionsphere. Approximately $\times 960$.

21 A transverse section through the posterior trunk region of a 47-hour embryo. Two germ cells are seen lying in the potential coelomic space to the left of the gut. Approximately $\times 360$.

22 A transverse section through the posterior trunk region of a 74-hour embryo, apparently less developed than that shown in figure 21. Two germ cells are present in the mesoderm to the right and left of the gut. Approximately $\times 250$. 

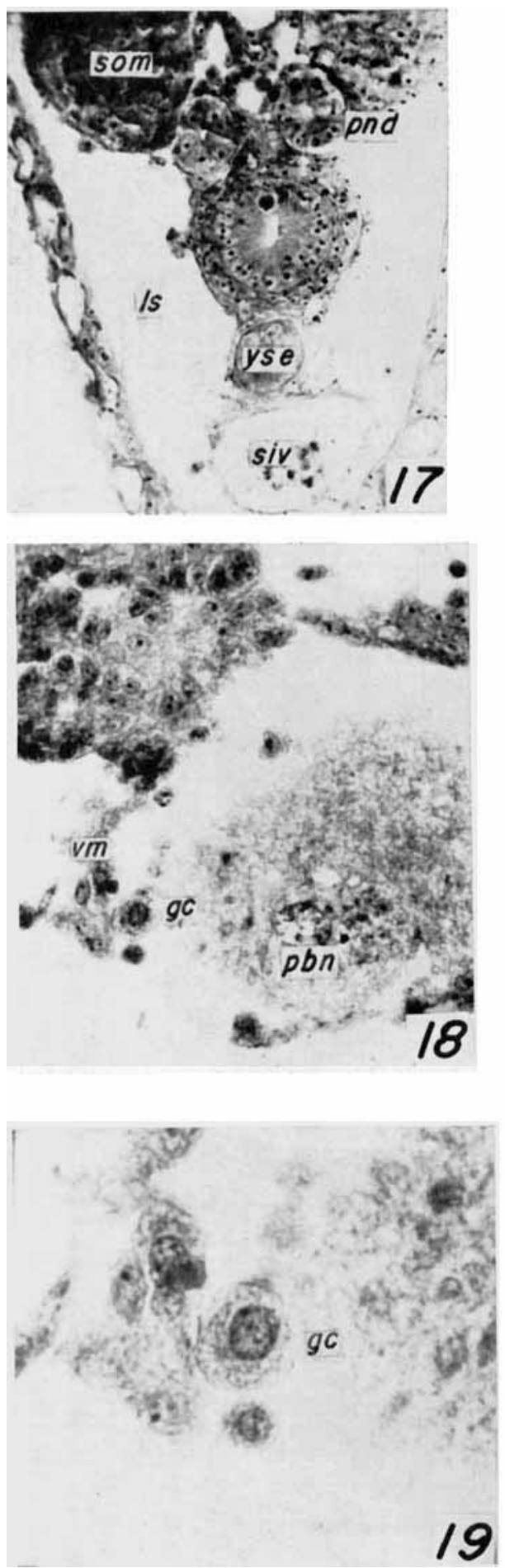
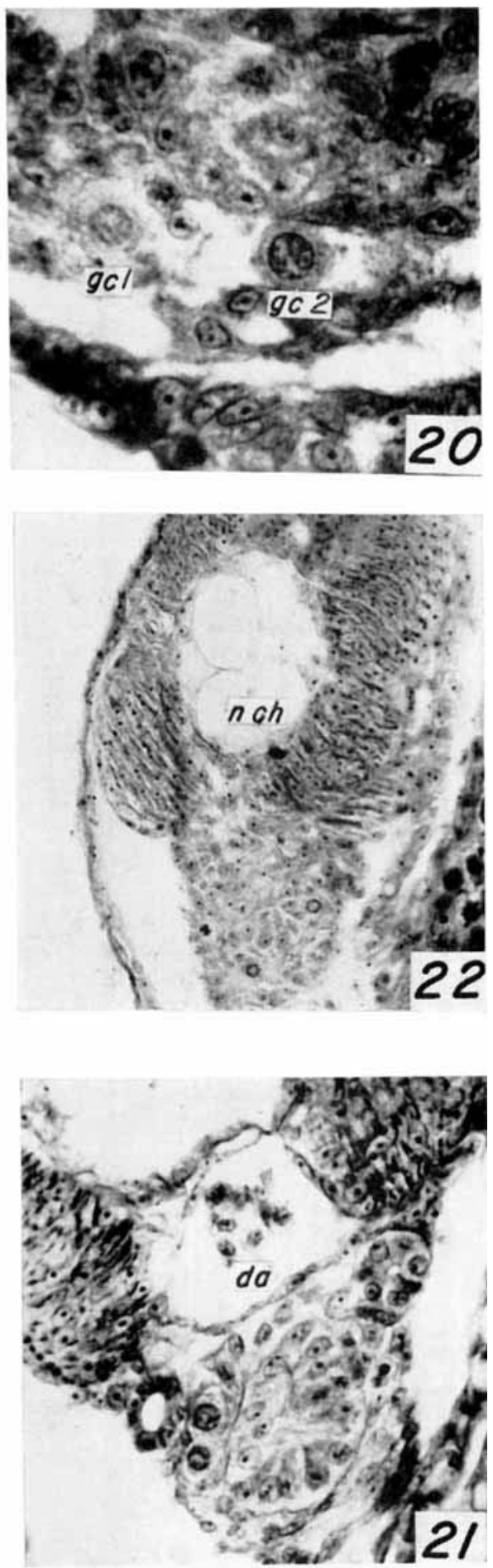


\section{PLATE 4}

\section{EXPLANATION OF FIGURES}

23 A cross section through the hindgut region of a $3.5-\mathrm{mm}$ larva $0-1$ days post hatching. Four germ eells may be seen, apparently lying, in the potential coelomic eavity. Careful observation will disclose that the two germ cells on the right are bordered both medially and laterally by flattened mesodermal cells. Approximately $\times 500$.

24 A cross section of the hindgut region of a 3.5-mm larva. A germ cell may be seen at the crest of the mesentery dorsal to the gut. Apparently this cell is passing through the splanchnic layer of the mesentery. The space (coe) to the left of this cell marks the beginning of the coelom, posteriorly. Approximately $\times 500$.

25 A transverse section through the hindgut region of a $4.0-\mathrm{mm}$ larva. Five germ cells (ge 1-5) lie in the dorsal mesentery. Approximately $\times 880$.

26 A longitudinal section of the hindgut region of a $4.5-\mathrm{mm}$ larva. Four germ cells (ge 1-4) may be seen lying dorsal to the gut and ventral to the pronephric duct (pnd). These cells are in the retroperitoneal stage of their migration. Approximately $\times 550$.

27 A transverse section through the hindgut region of a $5.0-\mathrm{mm}$ larva. Three germ cells (ge 1-3) may be seen lying dorsal to the dorsal mesentery. The coelomic spaces (coe) are well defined and are lined with a delicate mesothelium. Approximately $\times 550$.

28 A transverse section through the lindgut region of a $6.5-\mathrm{mm}$ larva. Four germ eells (ge 1-4) lie retroperitoneally; two ventral to the right and two ventral to the left pronephric duct. The beginning of the lateral shifting of the germ cells may be observed in this section. Approximately $\times 800$. 
PERRY MAX JOHNSTON
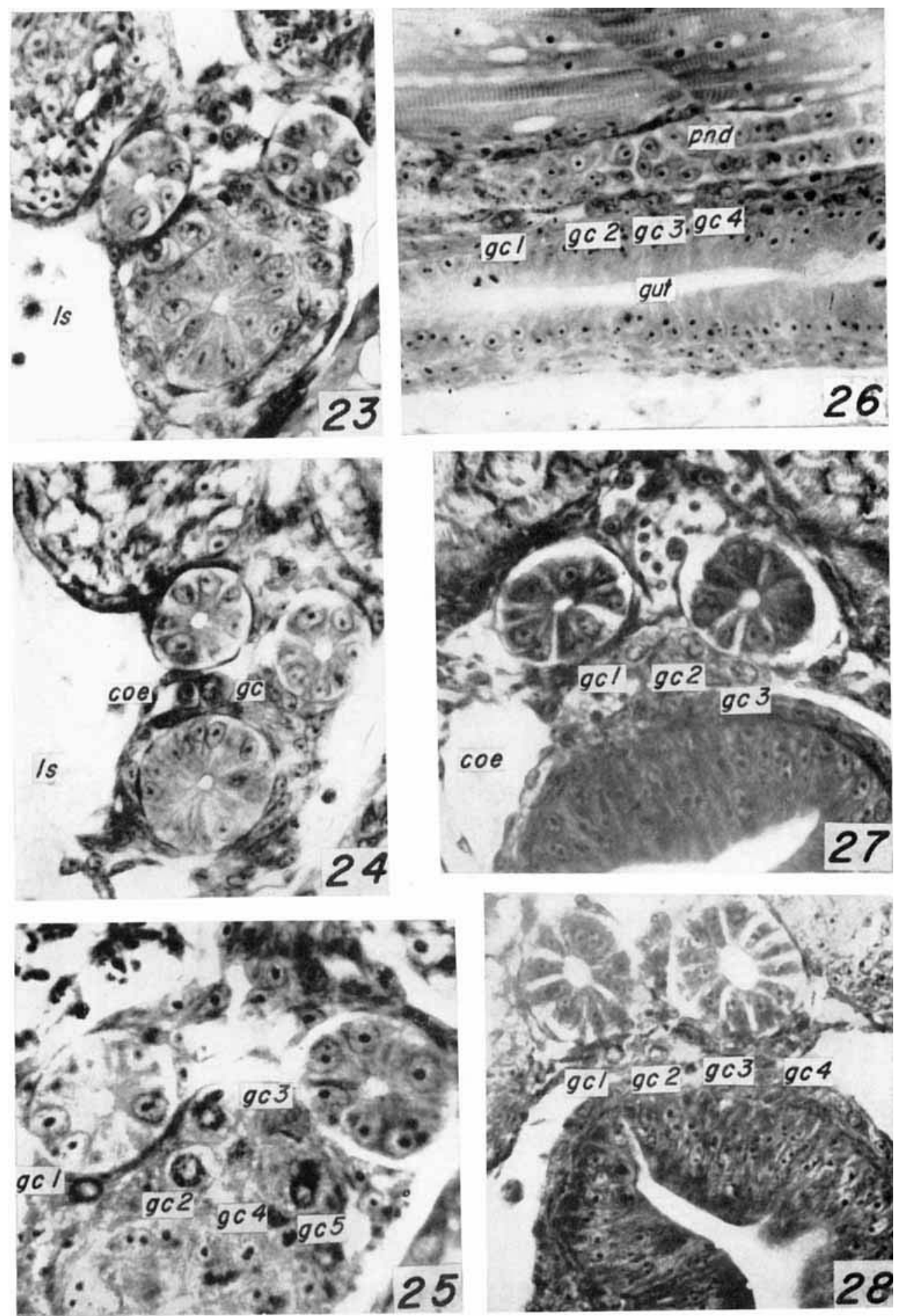


\section{PLATE 5}

\section{EXPLANATION OF FIGURES}

29 A cross section through the hindgut region of a $6.5-\mathrm{mm}$ fry. A germ cell (ge) may be seen lying ventral to the right pronephric duct. The gonad later forms in this immediate region. Approximately $\times 680$.

30 A transverse section through the hindgut region of an $8.0-\mathrm{mm}$ fry. Two germ cells are lying in the gonad primordia. Note how thin and delicate the dorsal mesentery now appears $(\mathrm{dm})$ and compare with figures of earlier stages. Approximately $\times 480$.

31 A transverse section through the hindgut region of an $8.0-\mathrm{mm}$ fry. Two germ cells lie in the left gonad primordium. Approximately $\times 480$.

32 A section of the gonad of an $8.0-\mathrm{mm}$ fry. The gonium is surrounded by a single layer of epithelial cells. Approximately $\times 500$.

33 A section of the gonad region of a 10.0-mm fry showing a germ cell being invested by a second layer of epithelial cells. It appears that these cells are migrating down and around the germ cell (gonium). Approximately $\times 1000$.

34 A transverse section of the gonad of an 11.0-mm fry. Two layers of epithelial cells cover the gonium. The inner layer may be considered as a follicular layer and the outer as a true epithelial layer. Approximately $\times 1000$. 

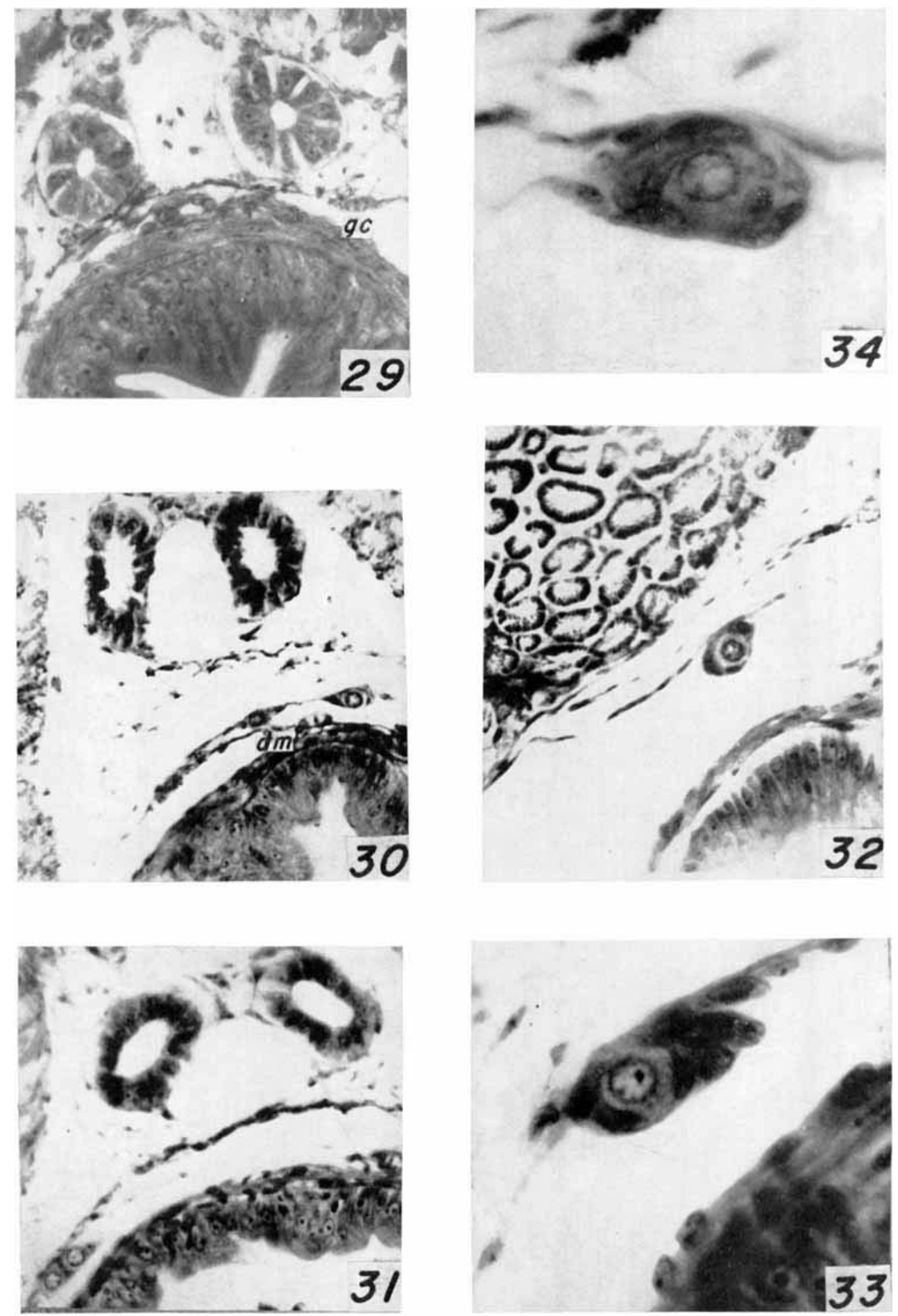


\section{PLATE 6}

\section{EXPLANATION OF FIGURES}

35 A section through the gonad of an 11.0-mm fry. The gonad hangs suspended in the coelom by a delicate mesentery. Approximately $\times 320$.

36 A cross section through the gonad of an 18.0-mm fry-fingerling. Separation of the epithelial and follicular layers has occurred, forming a space between them. The gonium is contained within the inner layer. The definitive adult relationship between the gonad and the swimbladder (sb) is established. Note the thin dorsal mesentery $(\mathrm{dm})$. Approximately $\times 400$.

37 A transverse section of the late indifferent gonad. Note the predominance of stroma. Approximately $\times 400$.

38 A cross section of the right and left ovaries of a sexually differentiated female $3 \mathrm{~cm}$ in length. Note the thickness of the connective tissue tunic and the broadness of the mesentery. Both ovaries possess an ovocoel (ove). Approximately $\times 250$.

39 A cross section of the fused ovaries of a $3 \mathrm{~cm}$ female. Approximately $\times 250$. 

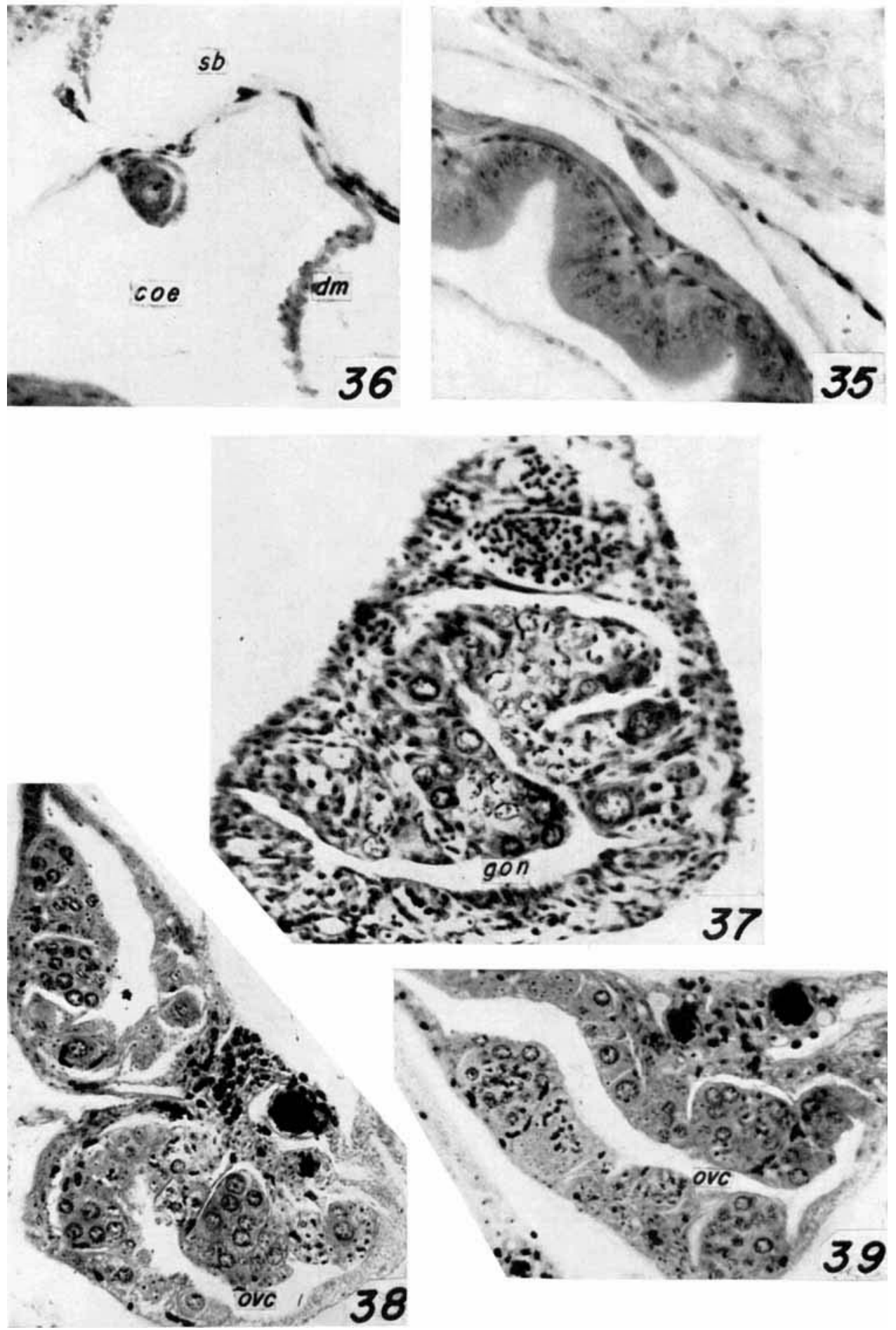


\section{PLATE 7}

\section{EXPLANATION OF FIGURES}

40 A section through the sinus formed by the fused ovocoels of the fused ovaries. Note that it lies in the dorsal mesentery $(\mathrm{dm})$ dorsal to the gut. Both a ventral and dorsal portion of the mesentery may be seen. Approximately $\times 250$.

41 A seetion taken posterior to that shown in figure 40 shows the relationship of the oviduct with the urinary bladder above (ub) and the gut below. Approximately $\times 250$.

42 A transverse section through the ovary of a $3 \mathrm{~cm}$ fingerling. Observe that the oocytes are contained within lamellae which project into the ovovoel. Approximately $\times 120$.

43 A seetion through the ovary of a $4.5-\mathrm{cm}$ fingerling. Note the arrangement of the chromatin along the nuclear membrane in the larger ooeytes. Note also the two regions, light and dark, of the eytoplasm of oocyte (a). Approximately $\times 250$.

44 A section through the ovary of a 3.5-em fingerling showing the eytoplasmie differentiation in the rapidly growing oocytes. This differentiation is particularly good in oocyte (a). Approximately $\times 340$. 


(j) की

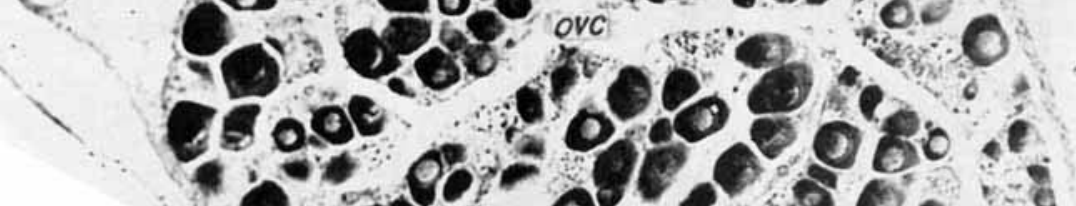



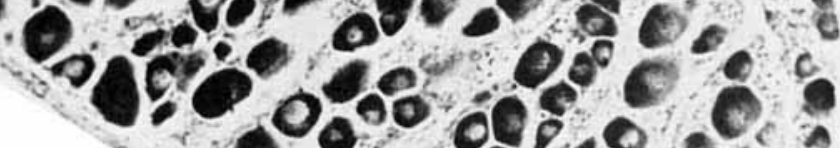

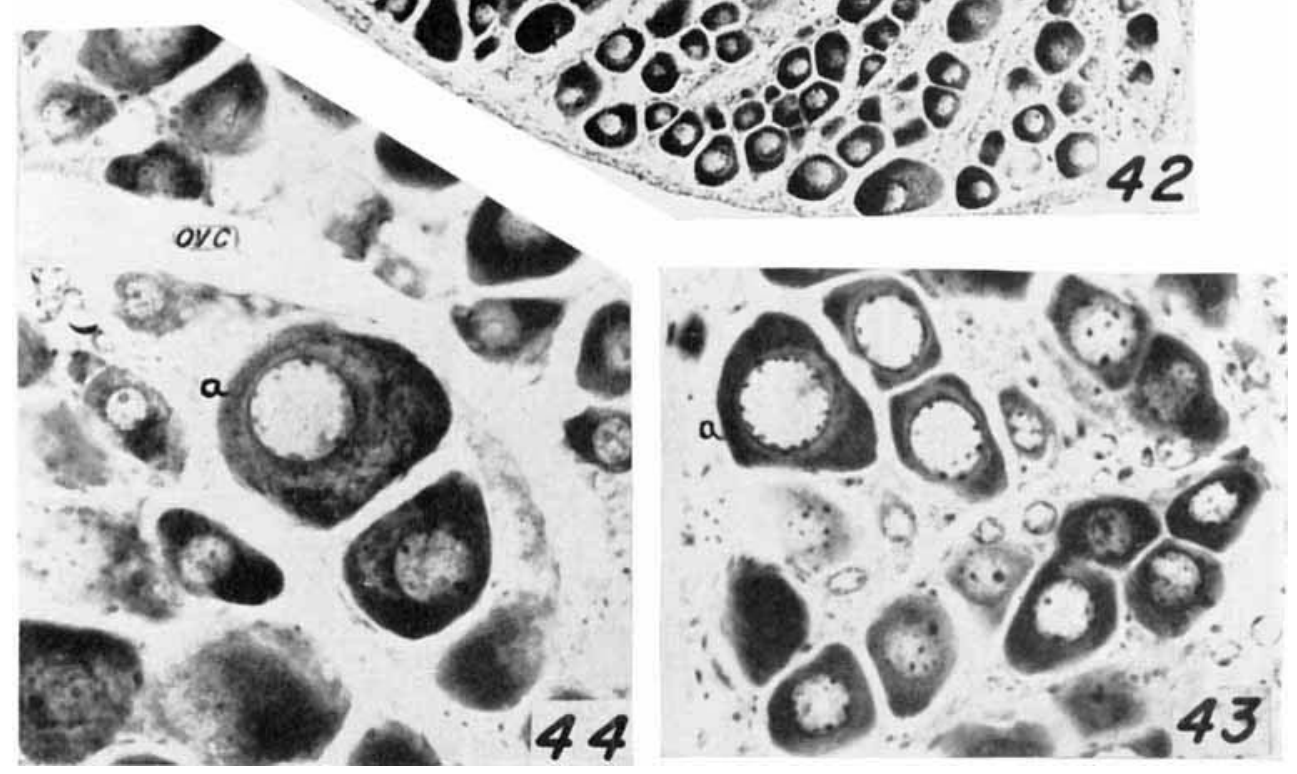




\section{PLATE 8}

\section{EXPLANATION OF FIGURES}

45 A transverse section through the anterior portion of the testis of a $4.0-\mathrm{cm}$ fingerling. Approximately $\times 350$.

46 A transverse section of the posterior portion of the testis of a $4.0-\mathrm{cm}$ fingerling. Note that the testocoel (tc) sends branches ( 1 and 2 ) into the stroma between the germ cells. Also note the tendency of the germ cells to arrange themselves around a potential lumen. Approximately $\times 350$.

47 A transverse section of the testis of a $6.0-\mathrm{cm}$ fingerling. Note the definite tubular condition of the testis. Observe that the germ cells (spermatogonia) are loeated in the walls of the tubules. Approximately $\times 350$.

48 A transverse section of the testis of a $6.0-\mathrm{cm}$ fingerling. This section is posterior to that shown in figure 47. The testicular duct (td) lies dorsomedially in the testis and in this section a branch is seen joining it. Approximately $\times 350$.

49 An enlargement of a portion of figure 47 to show how the germ cells (spermatogonia) may lie in the wall of the tubule but still not partieipate in the formation of its limiting membrane. This is shown very clearly in the lower tubule by spermatogonia $(x)$ and $(y)$. Careful observation will disclose that although spermatogonium $(x)$ appears to be a part of the surface membrane of the tubule, it is actually underlaid by epithelial cells. Approximately $\times 1050$. 

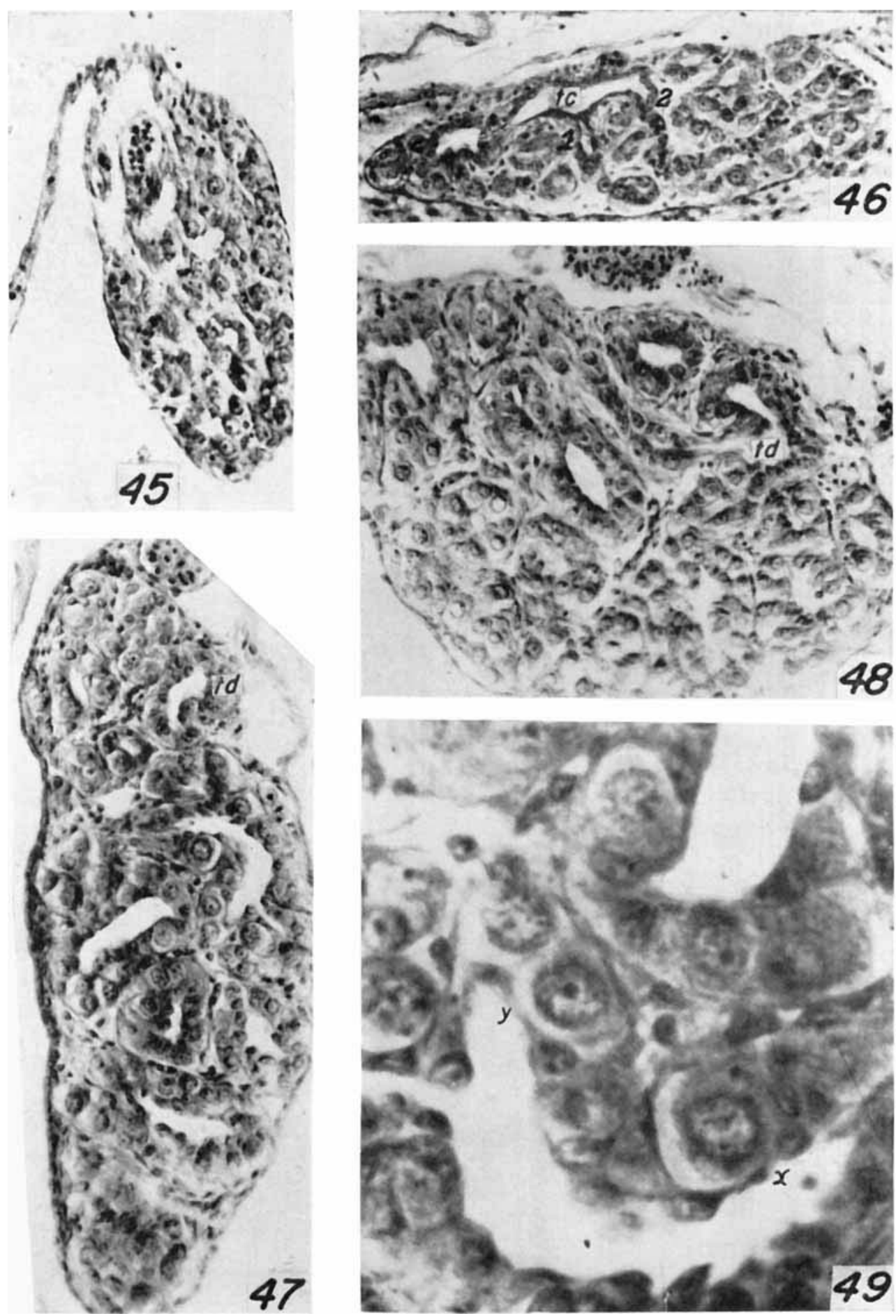
PLATE 9

EXPLANATION OF FIGURES

50 A ventral view of the ovaries and testes of $4.5 \cdot \mathrm{cm}$ fingerlings. Observe that the ovaries appear as distended elongate bodies while the testes appear as thin elongate strands. Approximately $\times 2.5$.

51 A ventral view of the ovaries of an $8.0-\mathrm{cm}$ bass in situ. The ovaries are suspended from the ventral face of the swimbladder by short mesovaria (mes). Observe that the ovaries fuse posteriorly and continue as a thin-walled sinus (gs). Approximately $\times 2$.

52 A lateral view of the testes, in situ, in a $7.0-\mathrm{cm}$ bass. The anteroposterior gradation in development is now discernible, grossly. The urinary bladder (ub) may be seen lying dorsal to the eut end of the gut. Approximately $\times 4.0$. 

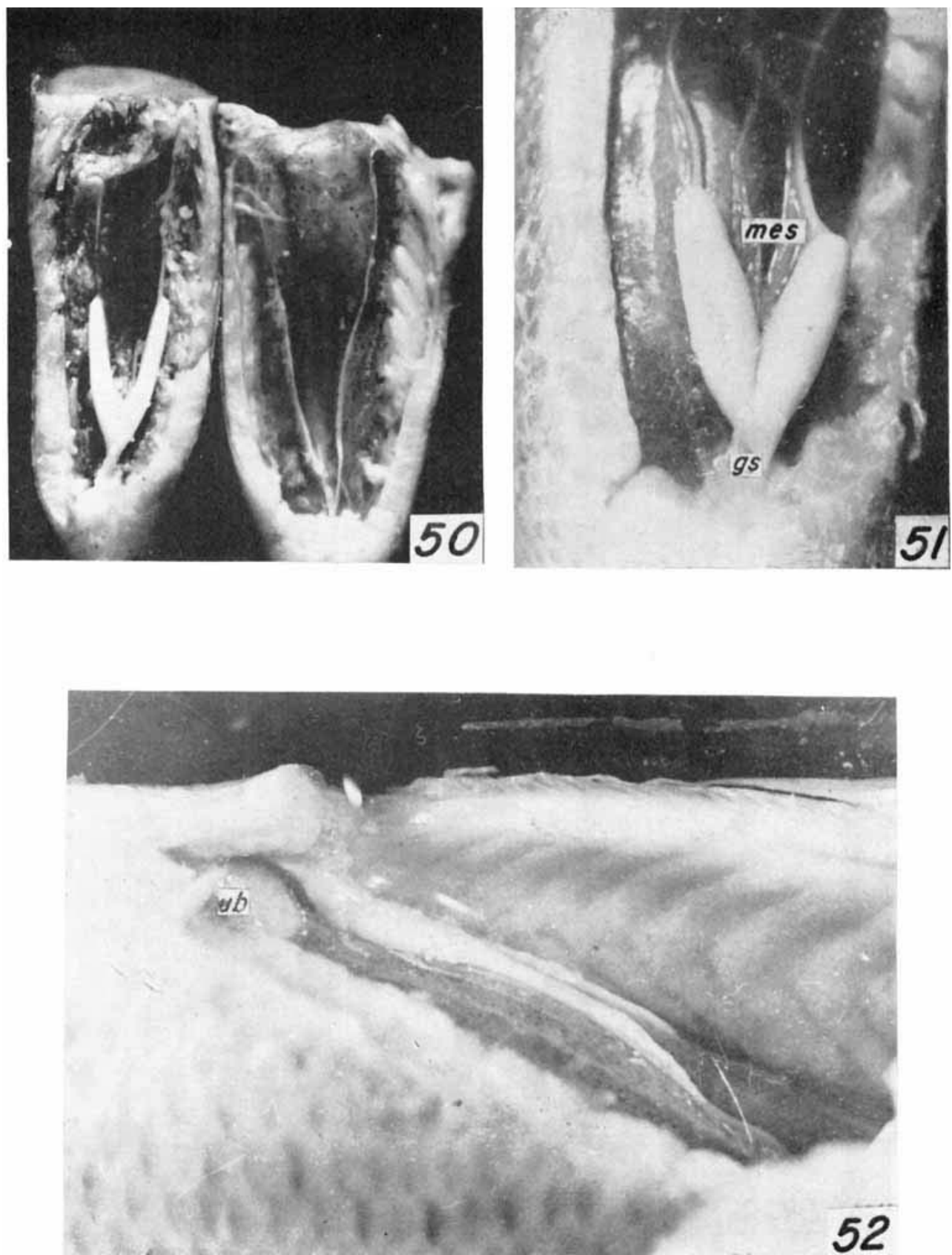


\section{APPENDIX}

Summary table of normal development for Micropterus salmoides salmoides (Lac.)

\begin{tabular}{|c|c|}
\hline $\begin{array}{l}\text { TIME AFTER } \\
\text { FERTILIZATION }\end{array}$ & $\begin{array}{l}\text { DEGREE OF DEVELOPMENT } \\
\text { ATTAINED }\end{array}$ \\
\hline $15 \mathrm{~min}$. & Streaming of protoplasm to form the blastodise. \\
\hline $30 \mathrm{~min}$. & $\begin{array}{l}\text { Blastodise becomes a swollen cap with the oil globule lying to } \\
\text { one side. }\end{array}$ \\
\hline $35-40$ min. & First cleavage furrow appears. \\
\hline $55-60 \mathrm{~min}$. & Second cleavage furrow appears. \\
\hline $75-80 \mathrm{~min}$. & Third cleavage furrow appears. \\
\hline $120-160 \mathrm{~min}$. & $\begin{array}{l}32 \text { to } 64 \text { cell stage, eleaving embryo now known as the blasto- } \\
\text { derm. }\end{array}$ \\
\hline $4 \mathrm{hrs}$. & $\begin{array}{l}\text { Cells of the blastoderm dividing rapidly; periblastic nuclei be- } \\
\text { ing formed from marginal cells of blastoderm; periblastic } \\
\text { ridge established surrounding blastoderm margin. }\end{array}$ \\
\hline $6 \mathrm{hrs}$. & $\begin{array}{l}\text { Peripheral periblast established; periblastic nuclei undergoing } \\
\text { mitotic divisions. }\end{array}$ \\
\hline $7-8 \mathrm{hrs}$. & $\begin{array}{l}\text { Periblastic nuclei begin migrating toward center of blastoderm } \\
\text { to establish central periblast. }\end{array}$ \\
\hline 8 hrs. & $\begin{array}{l}\text { Central periblast established; segmentation of blastoderm vir- } \\
\text { tually ceases; periblastic nuclei concentrate in region of oil } \\
\text { globule; periblastic nuclei undergo vacuolation; epidermic } \\
\text { stratum established. }\end{array}$ \\
\hline $8-9$ hrs. & $\begin{array}{l}\text { Gastrulation begins; blastoderm becomes eccentrically thinned } \\
\text { and fiattened and is thicker peripherally than centrally - } \\
\text { germ ring established; anterior and posterior poles of embryo } \\
\text { established; embryonic shield defined - mesentoderm invagi- } \\
\text { nated at dorsal lip (above oil globule); embryonic and extra- } \\
\text { embryonic regions established; germ ring begins to envelop } \\
\text { the yolk mass. }\end{array}$ \\
\hline
\end{tabular}

9-12 hrs. Germ ring continues to envelop yolk mass; equator of yolk reached by 10 th hour; embryonic shield enlarges, mesentoderm continues to invaginate; posterior pole of embryo remains stationary with respect to oil globule; "yolk plug", stages reached by 11th hour consisting primarily of oil globule.

12-14 hrs. Mesentoderm differentiates into mesoderm, notochord and entoderm; embryonic axis established through the formation of a ridge in ectoderm along median line of the embryonic shield; nerve wedge begins to form; mesentoderm ends in an enlarged mass in the future head region; entoderm consists of two lamellae one cell layer in thickness extending laterad to limits of embryonic shield and mesiad to, but not beneath, the notochord. 


TIME AFTER
FERTILIZATION $\begin{gathered}\text { DEGRE OF DEVELOPMENT } \\ \text { ATTAINED }\end{gathered}$

14-16 hrs. Germ ring continues to advance over the yolk mass to close the yolk plug; blastopore formed in eaudal mass, a mass of undifferentiated tissue later differentiating into the tail; blastopore is about $0.2 \mathrm{~mm}$ in diameter; mesoderm forms somites (4); notochord rounds up; entodermal lamellae move under notochord; neural wedge more definite.

16-18 hrs. Blastopore closes; tail bud forms in caudal mass; neural wedge deepens, cells appear to be "interlocked" indicating mesiad migration; mesodermal somites begin to arch dorsally along their mesial borders (7-8); embryo now slightly elevated above embryonic shield; notochord becomes more rounded than in previous stage; lateral plate (nephridiocoelomic) mesoderm differentiates; entoderm now everywhere a continuous lamella beneath the notochord; entodermal cells less flattened than before.

18-22 hrs. Tail begins to differentiate and grow; neural wedge in head region differentiates into fore, mid, and hind brain primordia; lateral optic thickenings occur in fore brain region; olfactory primordia formed in ectoderm; common sensory anlage formed in ectoderm lateral to brain; otic capsule differentiates opposite hind brain; mesodermal somites continue to arch dorsally (10); pronephric duct primordia differentiate from mesial border of nephridiocoelomic mesoderm; entodermal lamella begins to fold along mid-line in the trunk region to form the gut (somites 4-5); Küpffer's vesicle differentiates in entodermal mass of caudal region; gut differentiation begins in branchial region also.

22-26 hrs. Fore, mid and hind brain regions definitely established; olfactory anlage invaginates to form olfactory sacs; optic vesicles differentiate into retinal and choroidal layers; lens differentiates from common sensory anlage; ectodermal invaginations grow inward to join entodermal evaginations in branchial region; somites considerably arched dorsally (14-16); selerotomal, dermatomal and myotomal organization apparent; Küpffer's vesicle fully developed; notochordal cells vacuolating.

26-32 hrs. The entire embryo is considerably lengthened due to the rapid growth of the tail; the central canal is beginning to form in the nerve wedge; lens primordium more rounded than before, still connected to surface ectoderm; neural wedge shows differentiation of ependymal and mantle layers; the gut is a closed tube in some regions, open in others; Küpffer's vesicle enlarged and continuous with gut anteriorly; vascular organization beginning anterior and ventral to the head; myofibrils 


\begin{tabular}{|c|c|}
\hline $\begin{array}{l}\text { TLME AFTER } \\
\text { FERTILIZATION }\end{array}$ & $\begin{array}{l}\text { DEGREE OF DEVELOPMENT } \\
\text { ATTAINED }\end{array}$ \\
\hline $\begin{array}{l}26-32 \text { hrs. } \\
\text { (continued) }\end{array}$ & $\begin{array}{l}\text { appear in somites; pronephric ducts well defined, closed an- } \\
\text { teriorly and connecting posteriorly with hindgut; vacuolation } \\
\text { of notochord cells virtually complete; notochordal sheath } \\
\text { beginning to form; brain regions more clearly defined than } \\
\text { before. }\end{array}$ \\
\hline $32-42 \mathrm{hrs}$. & $\begin{array}{l}\text { No new structures make their appearance; tail continues to } \\
\text { grow and is compressed laterally; myotomes show beginnings } \\
\text { of differentiation into epaxial and hypaxial muscle masses; } \\
\text { body flexion noticeable; somites } 18-20 \text {; lens of eye almost } \\
\text { detached from surface ectoderm; divisions of brain better } \\
\text { differentiated than before. }\end{array}$ \\
\hline
\end{tabular}

42-hr. hatehing

The divisions of the brain are well developed; 1 st and 2 nd ventricles formed in forebrain; optic lobes are developing, cerebellar folds beginning; otocysts well developed; endolymphatic outgrowths present; olfactory vesicles in the form of a closed sac; lens of eye is disconnected from surface ectoderm and lies within optic cup; choroid fissure still open; central canal in nerve cord complete; notochord fully formed extending from infundibulum to tip of the tail; myofibrils well developed - considerable body movement; somites number 3336,11 before the anus and $22-24$ to the tip of the tail; no external indication of the formation of either upper or lower jaws; no pigmentation in eye; liver, gallbladder and swimbladder primordia are present; dorsal, caudal and anal fins broadly confluent; vascular organization much advanced over previous stage; the heart is a simple tube vertically oriented anterior to the head; one pair of aortic arches arch dorsally and pass mesiad of the optic cups over the optic stalk; the arches continue posteriorly and fuse in the otic region; after fusing, the aorta continues into the tail, doubles back as the caudal vein and courses ventrad around the cloaea to continue anteriad as the subintestinal and vitelline vein; posterior to otocysts, ducts of Cuvier course anterior and ventral across the yolk sae and enter the sinus venosus; the duets of Cuvier receive rudimentary post and anterior eardinals; the gut is an open tube posteriorly but more or less oceluded in region of the otocysts; posteriorly, the gut flares to receive the pronephric ducts; no anal opening is present there being an anal plate; the pronephrie ducts are open throughout and lie ventral to the myotomes and dorsolateral to the gut; the coelom is not yet formed, although there is evidence of delamination of the splanchnic and somatic mesoderm. 